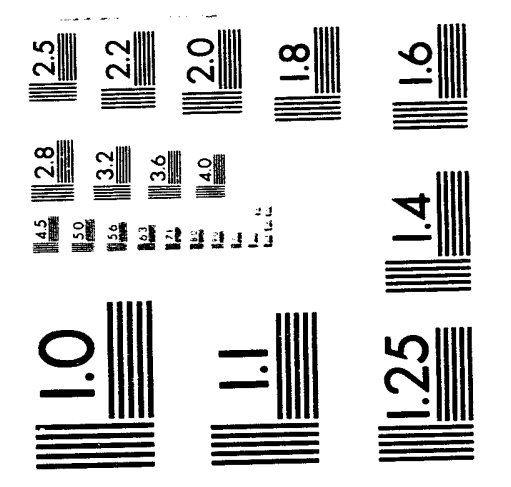



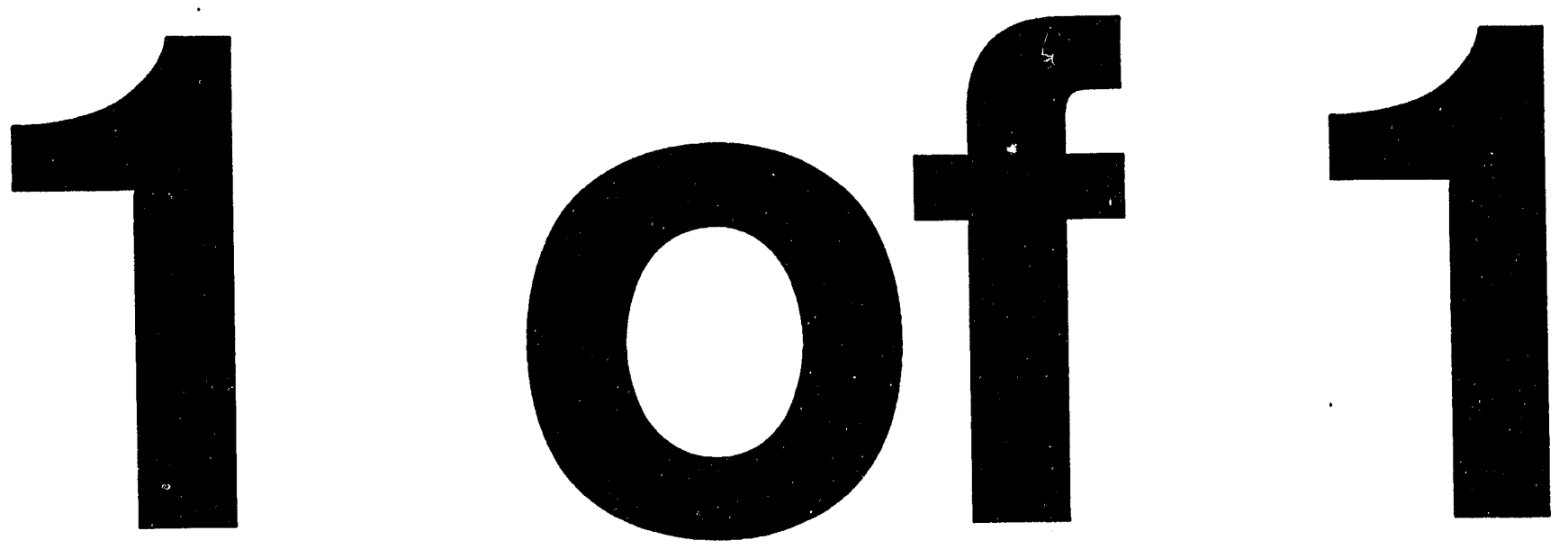
QUARTERLY TECHNICAL PROGRESS REPORT

NUMBER 8

\section{THE ECONOMICAL PRODUCTION OF ALCOHOL FUELS FROM COAL-DERIVED SYNTHESIS GAS}

CONTRACT NO. DE-AC22-91PC91034

\section{REPORTING PERIOD:}

July 1, 1993 to September 30, 1993

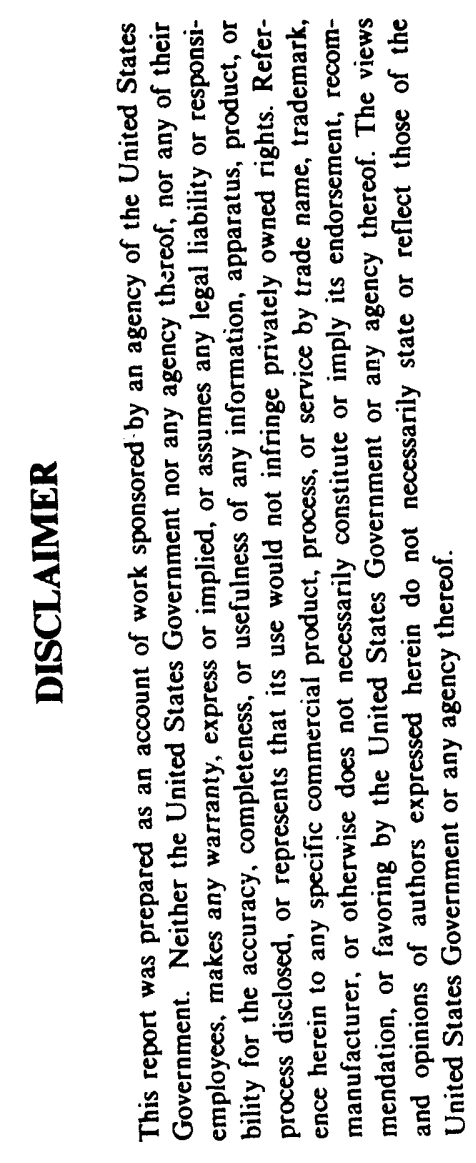

SUBMITTED TO:

Document Control Center

U.S. Department of Energy

Pittsburgh Energy Technology Center

P.O. Box 10940, MS 921-118

Pittsburgh, PA 15236-0940

\section{SUBMITTED BY:}

West Virginia University Research Corporation

on behalf of West Virginia University

213 Glenlock Hall

Morgantown, WV 26506

October, 1993

U.S. DOE Patent Clearance is not required prior to the publication of this document.

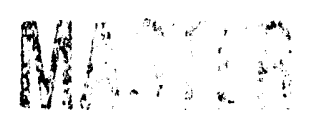

DSTRIBUTION OF THIS DOCUMEIVT IS UNLIMITED gFR 


\section{TABLE OF CONTENTS}

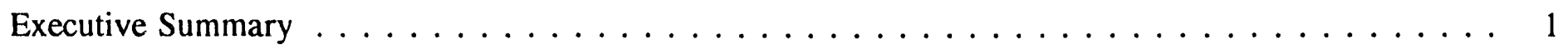

TASK 1. REACTION STUDIES

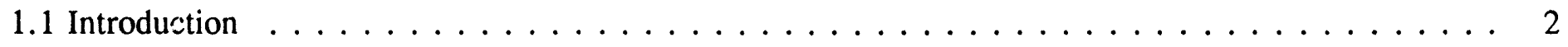

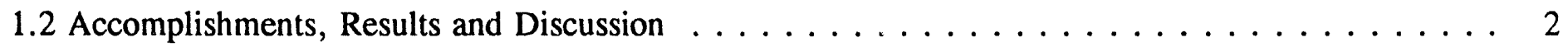

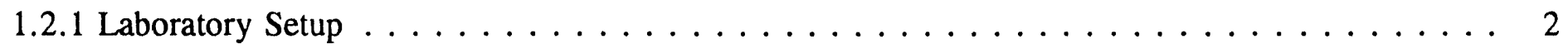

1.2.2 Molybdenum Based Catalyst Research $\ldots \ldots \ldots \ldots \ldots \ldots \ldots \ldots$

1.2.3 Transition Metal Oxide Catalyst Research $\ldots \ldots \ldots \ldots \ldots \ldots$

1.2.4 Reaction Engineering $\ldots \ldots \ldots \ldots \ldots \ldots \ldots \ldots \ldots \ldots \ldots \ldots \ldots \ldots \ldots \ldots \ldots \ldots \ldots \ldots \ldots \ldots$

1.3 Conclusions and Recommendations $\ldots \ldots \ldots \ldots \ldots$

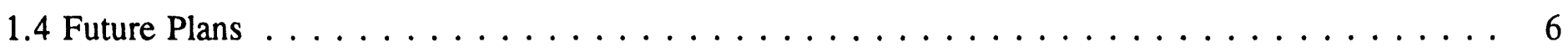

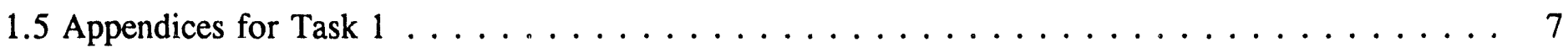

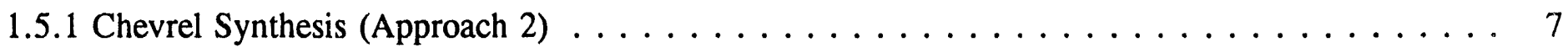

1.5.2 High-Temperature Vapor Phase Synthesis (Approach 3) $\ldots \ldots \ldots \ldots \ldots$

1.6 References for Task $1 \ldots \ldots \ldots \ldots \ldots \ldots \ldots$

TASK 2. PROCESS SYNTHESIS AND EVALUATION.

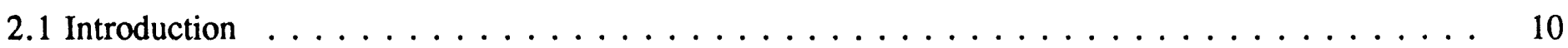

2.2 Accomplishments, Results and Discussion $\ldots \ldots \ldots \ldots \ldots$

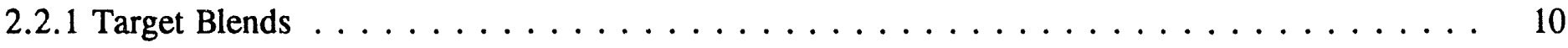

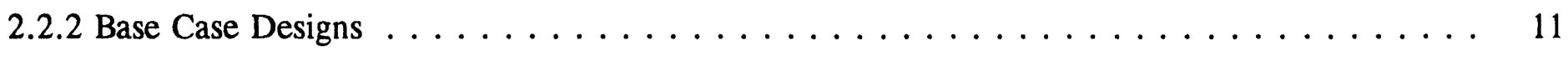

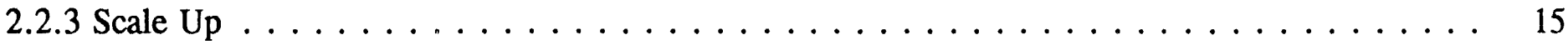

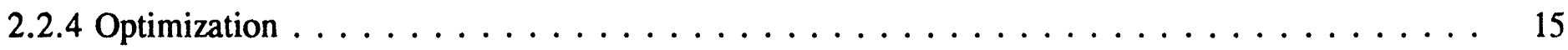




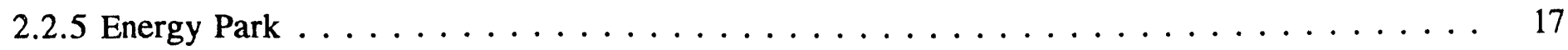

2.3 Conclusions and Recommenudions $\ldots \ldots \ldots \ldots \ldots$

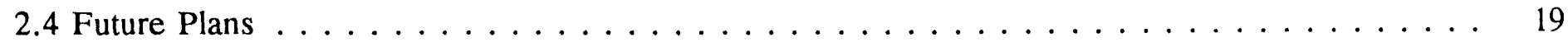

2.5 Appendix 1 for Task $2 \ldots \ldots \ldots \ldots \ldots \ldots$

2.6 References for Task $2 \ldots \ldots \ldots \ldots \ldots \ldots \ldots$ 


\section{LIST OF FIGURES}

Figure $1.1 \mathrm{X}$-ray powder diffraction patterns of $\ldots \ldots \ldots \ldots$

Figure 2.1 Payback Period for Base Cases $\ldots \ldots \ldots \ldots \ldots$

Figure 2.2 Mixed Alcohol Fuels $\ldots \ldots \ldots \ldots \ldots \ldots$

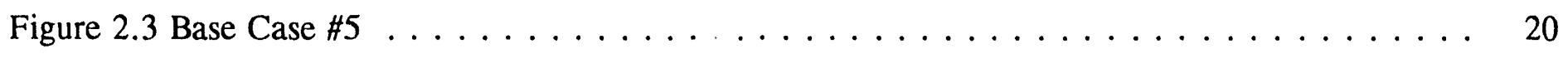

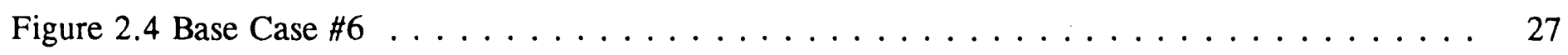




\section{LIST OF TABLES}

Table 1.1 Experimental Data from the Reaction $\ldots \ldots \ldots \ldots \ldots \ldots \ldots$

Table 1.2 List of parameters used in pressure drop calculations $\ldots \ldots \ldots \ldots$

Table 2.1 Estimated Value of Alcohol Fuel Additives $\ldots \ldots \ldots \ldots \ldots \ldots$

Table 2.2 Price of Reactants, Products and By-products $\ldots \ldots \ldots \ldots \ldots \ldots$

Table 2.3 Summary of Base Case Designs $\ldots \ldots \ldots \ldots \ldots \ldots$

Table 2.4 Summary of Costs for Base Cases $\ldots \ldots \ldots \ldots \ldots \ldots \ldots$

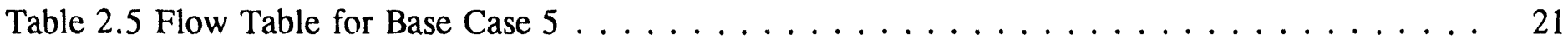

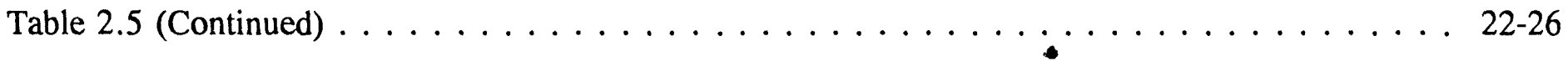

Table 2.6 Flow Tablu for Base Case $6 \ldots \ldots \ldots \ldots \ldots \ldots \ldots$

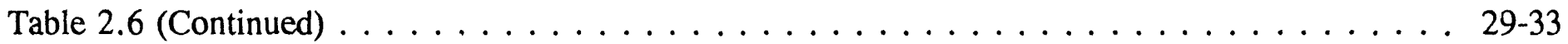




\section{Executive Summary}

In Task 1, the preparation of catalyst materials is proceeding actively. At WVU, catalysts based on molybdenum are being prepared using a variety of approaches to alter the oxidation state and environment of the molybdenum. This approach will continue into the next quarter, with some attention being paid to supported materials. At UCC\&P, copper-based zinc chromite spinel catalysts will be prepared and tested.

Construction of the WVU reactor units is complete, and control software has been loaded onto the computers. Actual interfacing of the computers to the reactors will precede "shake-down" runs with a standard methanol catalyst. At UCC\&P, a newly requisitioned gas chromatograph is expected to alleviate the previous problems in analysis.

The modelling of the alcohol-synthesis reaction in a membrane reactor is proceeding actively. Under standard conditions, pressure drop in the membrane reactor has been shown to be negligible. This is consistent with literature data for other systems.

In Task 2, base case designs had previously been completed with a Texaco gasifier, with either natural gas or a sour gas shift converter to adjust the unfavorable $\mathrm{H}_{2} / \mathrm{CO}$ ratio exiting the gasifier. Now, similar designs have been completed using the Shell gasifier. The alcohol synthesis reactor uses a $\mathrm{MoS}_{2}$ catalyst and is of a shell and tube design previously proposed by Union Carbide Corporation. A comparison of the payback periods or production cost of these plants shows significant differences among the base cases. However, a natural gas only design, prepared for comparison purposes, gives a lower payback period or production cost. Since the alcohol synthesis portion of the above processes is the same, the best way to make coal-derived higher alcohols mure attractive economically than natural gas-derived higher alcohols is by making coal-derived syngas less expensive than natural gas-derived syngas.

The maximum economically feasible capacity for a higher alcohol plant from coal-derived syngas appears to be $32 \mathrm{MM} \mathrm{bbl/yr}$. This is based on consideration of regional coal supply in the eastern United States, coal transportation, and regional product demand. The benefits of economics of scale are illustrated for the base case designs.

A value for higher alcohol blends has been determined by appropriate combination of RVP, octane number, and oxygen content, using MTBE as a reference. This analysis suggests that the high RVP of methanol in combination with its high water solubility make higher alcohols more valuable than methanol.

In the future, the most attractive base cases will be used to determine optimum plant size and operating conditions. Simulated annealing, a technique especially suited for optimization involving discrete choices, will be employed. Monte Carlo simulations will be used to study process and economic uncertainties. Fuel testing will be done to evaluate the combustion, emission and performance characteristics of fuel alcohols and gasoline blends. 


\section{TASK 1. REACTION STUDIES}

\subsection{Introduction}

The objective of Task 1 is to prepare and evaluate catalysts and to develop efficient reactor systems for the selective conversion of hydrogen-lean synthesis gas to alcohol fuel extenders and octane enhancers.

Task 1 is subdivided into three separate subtasks: laboratory and equipment setup; catalysis research; and reaction engineering and modeling. Research at West Virginia University (WVU) is focused on molybdenum-based catalysts. Parallel research being done at Union Carbide Chemicals and Plastics (UCC\&P) is focused on transition-metal-oxide catalysts.

\subsection{Accomplishments, Results and Discussion}

\subsubsection{Laboratory Setup}

Catalyst testing facilities at WVU are reaching the end of the construction phase. The reactors have been designed to operate at upto 1500 psi total pressure and up to $500^{\circ} \mathrm{C}$. Flow rates of inlet gases are monitored and controlled: upto $1000 \mathrm{scc} / \mathrm{min}$ for hydrogen, upto $500 \mathrm{scc} / \mathrm{min}$ for $\mathrm{CO}$, upto $500 \mathrm{scc} / \mathrm{min}$ for the hydrogen/hydrogen-sulfide mixture, and upto $1000 \mathrm{scc} / \mathrm{min}$ for a fourth gas, generally an inert. In addition, a liquid feed may be introduced, with flow rates of upto $10 \mathrm{cc} / \mathrm{min}$. For both reactors, the outlet sample will be obtained at the reactor pressure directly to the gas chromatograph. Using both TCD and FID detectors, the instrument will measure $\mathrm{CO}$, hydrocarbons, alcohols, hydrogen sulfide, carbon dioxide and water. Additional details on the unit designs can be found in TPR5.

The physical construction and plumbing of the units has been completed. The software installation for computer control is also complete. The control package used is "Intouch" by Wonderware. This is the same package used by UCC\&P. Remaining is the interfacing of the computers to the two reactors.

At UCC\&P, the previous problems with instrumentation have been resolved with the requisitioning of a new gas chromatograph.

\subsubsection{Molybdenum-Based Catalyst Research}

Conventional approaches to molybdenum-sulfide-based materials for higher-alcohol synthesis (HAS) have focused on the use of hexagonal molybdenum disulfide $\left(\mathrm{MoS}_{2}\right)$ modified with alkali metals. ${ }^{1,2}$ The alkali metals vary in their weight percent, up to about $20 \%^{2}$ of the material, and probably intercalate between sulfur layers in $\mathrm{MoS}_{2}{ }^{2}$ Doping $\mathrm{MoS}_{2}$ with alkali metals not only increases the basicity of the materials, but increases the catalytic activity of these materials toward HAS.

Catalyst preparations are being investigated using four approaches:

1) Synthesis and thermal decomposition of heterobimetallic inorganic and organometallic sulfide compounds for the preparation of supported and unsupported materials. 
2) Synthesis of Chevrel phase compounds, $\mathrm{M}^{\prime} \mathrm{Mo}_{6} \mathrm{~S}_{8}\left(\mathrm{M}^{\prime}=\mathrm{Sm}, \mathrm{Ho}, \mathrm{Pb}, \mathrm{Sn}, \mathrm{Ag}\right.$, In, $\mathrm{Co}, \mathrm{Fe}, \mathrm{Ni}, \mathrm{Cu}$ ), through the use of refractory and water soluble precursors.

3) Elevated temperature vapor phase synthesis of mixed metal sulfides and/or nitrides by the reaction of volatile metal carbonyls and/or halides with $\mathrm{H}_{2} \mathrm{~S}$ and ammonia.

4) Synthesis of supported and unsupported molybdenum nitride compounds by thermal decomposition of a molecular molybdenum azide compound ("MoNN ${ }_{3}$ Py").

Through Approach 2, in addition to cation size, the oxidation state (basicity) can be varied by the selection of the appropriate ternary metal and the amount of this metal in the phase. Approaches 1 and 3 rely on mixing metals at the molecular level prior to thermal processing, which has the potential of producing materials unobtainable from conventional syntheses. Results in these four areas are given in the following sub-sections.

\section{Approach 1}

The focus of this approach is to make the organometallic products illustrated in the following five reactions:

$$
\begin{aligned}
\mathrm{Cp}_{2} \mathrm{Fe}_{2} \mathrm{~S}_{2}(\mathrm{CO})_{6}+\mathrm{Cp}_{2} \mathrm{Mo}_{2}(\mathrm{CO})_{4} \longrightarrow \mathrm{Cp}_{2} \mathrm{Mo}_{2} \mathrm{Fe}_{2} \mathrm{~S}_{2}(\mathrm{CO})_{8}+2 \mathrm{CO} \\
\mathrm{Cp}_{2} \mathrm{Mo}_{2}(\mu-\mathrm{S})_{2}(\mu-\mathrm{SH})_{2}+\mathrm{Co}_{2}(\mathrm{CO})_{8} \longrightarrow \mathrm{Cp}_{2} \mathrm{Mo}_{2} \mathrm{Co}_{2} \mathrm{~S}_{3}(\mathrm{CO})_{4}+4 \mathrm{CO} \\
\left.\left(\mathrm{Et}_{4} \mathrm{~N}\right)_{2} \mathrm{M}(\mathrm{SPh})_{4}+2 \mathrm{Mo}(\mathrm{CO})_{4} \mathrm{C}_{7} \mathrm{H}_{8} \longrightarrow \mathrm{NEt}_{4}\right)_{2}\left\{\mathrm{M}(\mathrm{SPh})_{4}\left[\mathrm{Mo}(\mathrm{CO})_{4}\right]_{2}\right\} \\
(\mathrm{M}=\mathrm{Co}, \mathrm{Ni}) \\
\left(\mathrm{C}_{5} \mathrm{Me}_{5}\right)_{2} \mathrm{Mo}_{2}\left(\mathrm{~S}_{2}\right) \mathrm{S}_{2}+\mathrm{Co}_{2}(\mathrm{CO})_{8} \longrightarrow \mathrm{Cp}_{2} \longrightarrow \mathrm{Mo}_{2} \mathrm{Co}_{2} \mathrm{~S}_{4}(\mathrm{CO})_{2}+6 \mathrm{CO} \\
\mathrm{Cp}_{2} \mathrm{Mo}_{2}(\mu-\mathrm{S})_{2}(\mu-\mathrm{SH})_{2}+\mathrm{Fe}_{2}(\mathrm{CO})_{9} \longrightarrow \mathrm{Cp}_{2} \mathrm{Mo}_{2} \mathrm{Fe}_{2} \mathrm{~S}_{4}(\mathrm{CO})_{6}+3 \mathrm{CO}
\end{aligned}
$$

Except for the $\mathrm{Ni}$ and $\mathrm{Co}$ thiophenol salts, each of the reactants has been synthesized and purified. The student hired for this research completed his work on August 14, 1993 and is now attending graduate school.

\section{Approach 2}

An alternate method for making the Chevrel phase materials was developed. A cobalt Chevrel phase $\left(\mathrm{Co}_{1.63} \mathrm{Mo}_{6} \mathrm{~S}_{8}\right)$ has been made using only a mixture of the elements, whereas typical syntheses of Chevrel phases involve the use of molybdenum sulfide $\left(\mathrm{Mo}_{2} \mathrm{~S}_{3}\right)$, molybdenum metal and the sulfides of the ternary metal. Details of the experimental procedure are given in Appendix 1.5.1. The X-ray powder diffraction pattern of the prepared cobalt Chevrel phase matched a pattern of previously prepared $\mathrm{Co}_{1.63} \mathrm{Mo}_{6} \mathrm{~S}_{8}$ from JCPDS. There were no extraneous lines.

Two grams of each of the following Chevrel phases $\left(\mathrm{HoMo}_{6} \mathrm{~S}_{8}, \mathrm{SmMo}_{6} \mathrm{~S}_{8}, \mathrm{SnMo}_{6} \mathrm{~S}_{8}, \mathrm{AgMo}_{6} \mathrm{~S}_{8}, \mathrm{InMo}_{6} \mathrm{~S}_{8}\right.$, $\mathrm{Cu}_{3.2} \mathrm{Mo}_{6} \mathrm{~S}_{8}, \mathrm{Fe}_{1.5} \mathrm{Mo}_{6} \mathrm{~S}_{8}, \mathrm{Ni}_{1.6} \mathrm{Mo}_{6} \mathrm{~S}_{8}, \mathrm{Co}_{1.63} \mathrm{Mo}_{6} \mathrm{~S}_{8}$ ) are being prepared.

\section{Approach 3}

For the vapor-phase synthesis at elevated temperatures, a systematic study was completed in which the effect of furnace temperature on phase formation and material surface area of the products was 
evaluated. The system used was $\mathrm{Mo}(\mathrm{CO})_{6}$ and $\mathrm{H}_{2} \mathrm{~S}$. Experimental details are given in Appendix 1.5.2. The phase formation was monitored by x-ray powder diffraction; see Figure 1. Nitrogen adsorption was used for the evaluation of the surface areas, with the BET model for evaluation; see Table I.

Table 1.1 Experimental Data from the Reaction Between $\mathrm{Mo}(\mathrm{CO})_{6}$ and $\mathrm{H}_{2} \mathrm{~S}$, Illustrating the Correlation Between the Furnace Temperature of the Reaction and the Surface Area of the Resulting $\mathrm{MoS}_{2}$ Product.

\begin{tabular}{|l|l|l|l|}
\hline Product Formed & Temperature, ${ }^{\circ} \mathrm{C}$ & $\begin{array}{l}\text { Surface Area, }{ }^{2} / \mathrm{g} \\
\text { (BET Method) }\end{array}$ & $\begin{array}{l}\text { Particle Size } \\
\text { Diameter, }{ }^{\circ} \mathrm{nm}\end{array}$ \\
\hline $\mathrm{MoS}_{2}$ & 500 & 82 & 15 \\
\hline $\mathrm{MoS}_{2}$ & 900 & 30 & 42 \\
\hline $\mathrm{MoS}_{2}$ & 1100 & 17 & 78 \\
\hline
\end{tabular}

Based on a spherical particle geometry and a $\mathrm{MoS}_{2}$ density of $4.8 \mathrm{~g} / \mathrm{cm}^{3}$.

In Figure 1, all the diffraction patterns are similar and can be indexed to the hexagonal $\mathrm{MoS}_{2}$. The large peaks observed at $37^{\circ}$ and $78^{\circ}$ in pattern $\mathrm{B}$ and $\mathrm{D}$ are due to the $\mathrm{Al}$ sample holder. This result illustrates the broad temperature range over which $\mathrm{MoS}_{2}$ can be formed under these conditions. In Table I, a direct correlation can be seen between reaction temperature and particle size. This trend indicates that $\mathrm{MoS}_{2}$ with surface areas in excess of $82 \mathrm{~m}^{2} / \mathrm{g}$ can be formed at temperatures lower than $500^{\circ} \mathrm{C}$; therefore, the next step in this approach is to determine the low-temperature cutoff for $\mathrm{MoS}_{2}$ formation. Without testing the materials for catalytic ability, it is difficult to assess their utility for HAS, although the relatively high $\mathrm{MoS}_{2}$ surface areas obtained from this technique are encouraging.

\section{Approach 4}

The azide material produced for this approach has previously been decomposed thermally to a molybdenum nitride and is ready for catalytic testing (see TPR7).

\subsubsection{Transition-Metal-Oxide Catalyst Research}

Research was severely limited by the temporary unavailability of UCC\&P personnel. The problem was brought about by the pending retirement of two key personnel, and the resulting reorganization and reassignment of staff. We are working our way out of the problem by the shifting of most catalyst synthesis research to the UCC\&P Catalysis Skill Center.

A quart of a standard methanol-synthesis catalyst was sent to WVU. This will allow the commissioning of the newly set-up reactors.

Preparations are underway to synthesize some zinc chromite spinel materials containing copper metal. 


\subsubsection{Reaction Engineering}

A model for a packed-bed/membrane reactor for conducting higher alcohol synthesis was developed and presented in the last quarterly report (TPR7). It was shown there that a packed-bed/membrane reactor could lead to a higher production of higher alcohols as compared to a conventional packed bed reactor. Total pressure drop inside the reactor, however, was not taken into account in the model. This has been taken care of during the present reporting period by adding two more equations to the twelve ordinary differential equations (ODEs) listed in Table 1.1 of TPR7. The Ergun equation ${ }^{4}$

$-\left(d P_{t} / d z\right)=\left(150 \mu v_{z} / D_{p}^{2}\right)(1-\epsilon)^{2} / \epsilon^{3}+\left(1.75 \rho v_{z}^{2} / D_{p}\right)(1-\epsilon)^{2} / \epsilon^{3}$

is used to account for the pressure drop in the tube (packed bed) side. For the pressure drop in the shell (permeate) side, the equation below ${ }^{4}$ is used:

$-(\mathrm{dP} / \mathrm{dz})=8 \mu v_{\mathrm{z}}, \ln \left[\mathrm{R}_{2} / \mathrm{R}_{1}\right] /\left\{\left(\mathrm{R}_{2}{ }^{2}+\mathrm{R}_{1}^{2}\right) \ln \left[\mathrm{R}_{1} / \mathrm{R}_{2}\right]+\left(\mathrm{R}_{2}{ }^{2}-\mathrm{R}_{1}{ }^{2}\right)\right\}$

Note that $P_{t}$ and $P_{s}$ are the total pressures in the tube and shell sides respectively, $v_{z}$ and $v_{z}$ ' are the velocities in the tube and shell sides respectively, and $R_{1}$ and $R_{2}$ are the radii of the membrane tube and reactor (shell side) respectively. Also, $D_{p}$ is the diameter of the catalyst particle in the packed bed, and $\epsilon$ the porosity of the packed bed.

The 14 ODEs are again solved using LSODE, a stiff ODE solver 5 . The parameters of the model are given in Table II. These numbers are consistent with those used in earlier calculations, in TPR7.

Table 1.2 List of parameters used in pressure drop calculations.

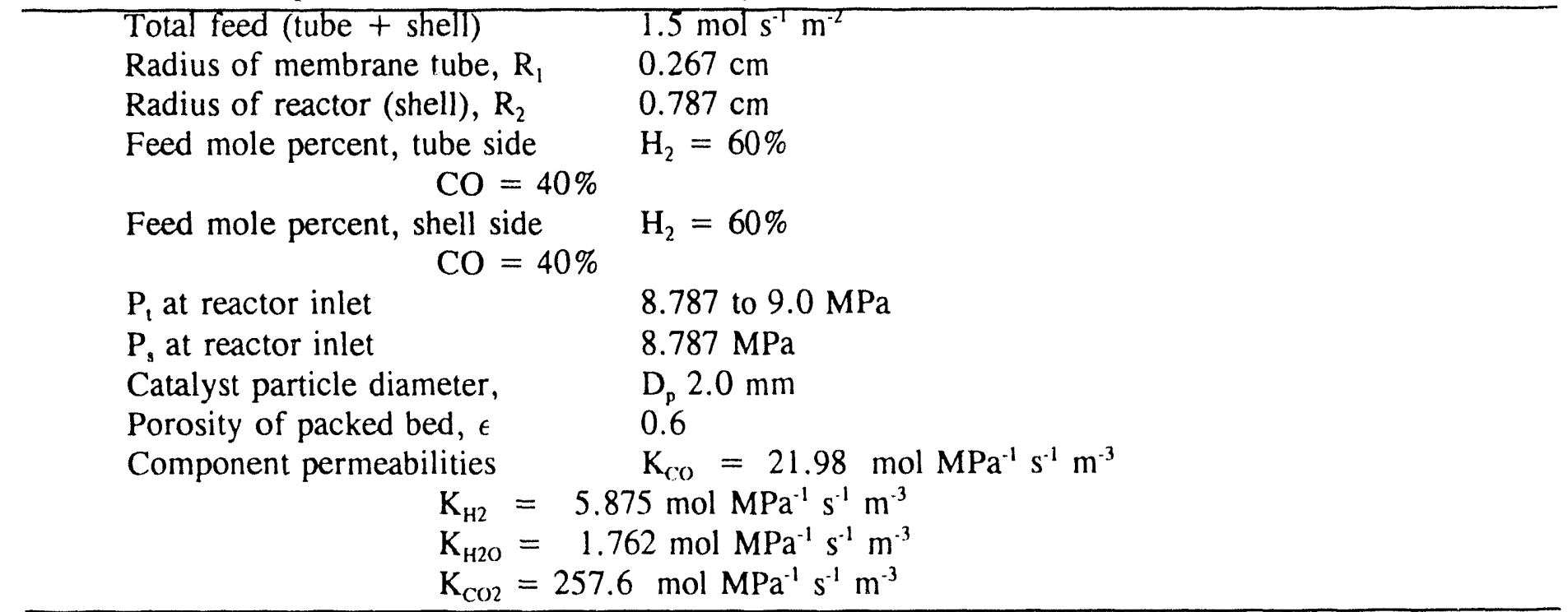

The results obtained so far indicate that pressure drops in both the tube and shell sides of the reactor are negligibly small, and hence would not cause significant change in the distribution of various products and 
reactants. This preliminary conclusion concerning total pressure variation is consistent with the assumption of negligible pressure drops used by a number of research groups ${ }^{6-10}$ for similar types of membrane reactors.

Reaction Engineering work at UCC\&P was similarly restricted by the temporary unavailability of key personnel, aggravated by an exceptionally high workload of high-priority commercial work in the Reaction Engineering Laboratories. We believe that these problems will be resolved by the planned assignment of additional staff to these laboratories.

\subsection{Conclusions and Recommendations}

Regarding the design of HAS catalyst, the oxidation state and environment of the molybdenum appear to be important variables relating to catalytic behavior. Therefore, built into each of the four approaches described in Section 1.2.2 is the ability to vary the oxidation state of molybdenum. This can be accomplished by varying the metal:sulfur ratio and/or decomposition environments in approach 1 ; by changing the amount or type of ternary metal used in approach 2 ; by varying type and ratios of gases used in the high temperature reactions in approach 3; and by doping the molybdenum nitride with alkali by mixing alkal. acetate with the azide prior to thermal decomposition in approach 4.

Regarding the reactor design, the packed-bed/membrane reactor does not require a significant pressure drop.

\subsection{Future Plans}

Each product of Approach 1 (Section 1.2.2, reactions (1)-(5)) will be thermally decomposed on highsurface-area supports, either silica or carbon. In addition to the variables of metal and sulfur ratio, defined by the stoichiometry of the materials, two decomposition variables will be investigated for the supported mixed metal compounds. Eacn product will be decomposed in four ways: at $350^{\circ} \mathrm{C}$ and $500^{\circ} \mathrm{C}$, and under $\mathrm{He}$ and $\mathrm{H}_{2} \mathrm{~S}$. The structures, surface areas and catalytic activities will then be determined.

The samples of the Chevrel phases noted in Approach 2, Section 1.2.2 (HoMo $\mathrm{S}_{8}, \mathrm{SmMo}_{6} \mathrm{~S}_{8}, \mathrm{SnMo}_{6} \mathrm{~S}_{8}$, $\mathrm{AgMo}_{6} \mathrm{~S}_{8}, \mathrm{InMo}_{6} \mathrm{~S}_{8}, \mathrm{Cu}_{3.2} \mathrm{Mo}_{6} \mathrm{~S}_{8}, \mathrm{Fe}_{1.5} \mathrm{Mo}_{6} \mathrm{~S}_{8}, \mathrm{Ni}_{1.6} \mathrm{Mo}_{6} \mathrm{~S}_{8}, \mathrm{Co}_{1.63} \mathrm{Mo}_{6} \mathrm{~S}_{8}$ ) will be characterized using X-ray powder diffraction, surface area analysis and possibly XPS, prior to the reactor studies. A collaboration with a surface scientist in Florida is currently being investigated for the XPS studies.

For the azide precursor approach, Approach 4, future work includes the preparation of a supported metal nitride and a systematic investigation of the influence of alkali doping on the catalytic behavior of these supported and unsupported molybdenum nitrides.

In other future efforts, emphasis will be placed on extending this approach to the preparation of molybdenum nitrides and mixed metal Co-Mo and Fe-Mo sulfide materials.

Copper-containing zinc chromite spinels will be synthesized at UCC\&P. These are expected to have interesting properties at typical low-temperature conditions characteristic of copper catalysts in synthesis-gas 
service.

The WVU reactors described in Section 1.2.1 will be interfaced with the computers. The reactors will be tested first using the standard methanol-synthesis catalyst provided by UCC\&P. Other catalysts will be tested after the reactors have been "shaken down" with the methanol-synthesis catalyst.

Modeling work will continue to focus on the potential for new reactor designs.

\subsection{Appendices for Task 1}

\subsection{1 - Chevrel Synthesis (Approach 2)}

The materials were purified to -emove all oxygen and water. Molybdenum metal was heated under flowing hydrogen gas at $1000^{\circ} \mathrm{C}$ fur 12 hours. The ternary metals were heated under flowing hydrogen at $500^{\circ} \mathrm{C}$ for 12 hours or, in the case of the rare earths, obtained directly from Strem Chemicals. The sulfur was purified by sublimation. Each of these reactants was stored in a dry box prior to use.

In a typical preparation of a Chevrel phase compound, the elements were intimately mixed by grinding in an agate mortar. The elemental mixture was transfencd to a $1-\mathrm{cm}$ diameter die and pressed into a pellet at 51,000 psi and transferred to the "dry" quartz reaction tube, which was then sealed under vacuum. The sealed quartz tube was heated to $700^{\circ} \mathrm{C}$ at $230^{\circ} \mathrm{C} / \mathrm{hr}$, heated at $700^{\circ} \mathrm{C}$ for 3 hours and then heated to $1200^{\circ} \mathrm{C}$ at $700^{\circ} \mathrm{C} / \mathrm{hr}$ and allowed to remain at $1200^{\circ} \mathrm{C}$ for 15 minutes. After heating, the sample was quenched in air. The resulting Chevrel-phase material was isolated and stored in a dry box. This synthesis eliminates the need for the additional steps of binary sulfide preparation.

\subsubsection{High-Temperature Vapor Phase Synthesis (Approach 3)}

In each of the reactions of $\mathrm{Mo}(\mathrm{CO})_{6}$ and $\mathrm{H}_{2} \mathrm{~S}$, flow rates and sublimation temperatures were maintained at the same value -- flow rates of $\mathrm{He}$ at between 400 to $450 \mathrm{ml} / \mathrm{min}$, of $\mathrm{H}_{2} \mathrm{~S}$ at $14 \mathrm{ml} / \mathrm{min}$; sublimation temperature at $69^{\circ} \mathrm{C}$. There were five experiments, conducted at temperatures of $500,800,900,1000$, and $1100^{\circ} \mathrm{C}$. $\mathrm{H}_{2} \mathrm{~S}$ was added to the He stream prior to flowing over the volatile $\mathrm{Mo}(\mathrm{CO})_{6}$, as opposed to admitting the reactive gas in the hot zone, effectively bypassing the $\mathrm{Mo}(\mathrm{CO})_{6}$. For each of the five reactions, approximately 1 hour was required for the reaction to go to completion. The products were isolated in a dry box. 


\subsection{References for Task 1}

1. Herman, R. G. Stud. Surf. Sci. Catal. 64, 265 (1991).

2. Kinkade, N. E., Eur. Pat. Appl. 84116467.6 and 84116468.4 (Dec. 28, 1984); assigned to Union Carbide Corporation.

3. Somoano, R. B.; Hadek, V.; Rembaum, A. J. Chem. Phys. 58, 697 (1973).

4. Wu, J.C.S.; Liu, P.K.T. Ind. Eng. Chem. Res. 31, 322 (1992).

5. Schiesser, W.E., "The Numerical Method of Lines", Academic Press (1991).

6. Agarwalla, S.; Lund, C.R.F. J. Mem. Sci. 70, 129 (1992).

7. Itoh, N.; Govind, R.M. Ind. Eng. Chem. Res. 28, 1554 (1989).

8. Itoh, N.; Shindo, Y.; Haraya, K.; and Hakuta, T. J. Chem. Eng. Japan 21, 399 (1988).

9. Mohan, K.; Govind, R. AIChE J. 12, 2083 (1986).

10. Sun, Y.; Khang, S. Ind. Eng. Chem. Res. 29, 232 (1990). 


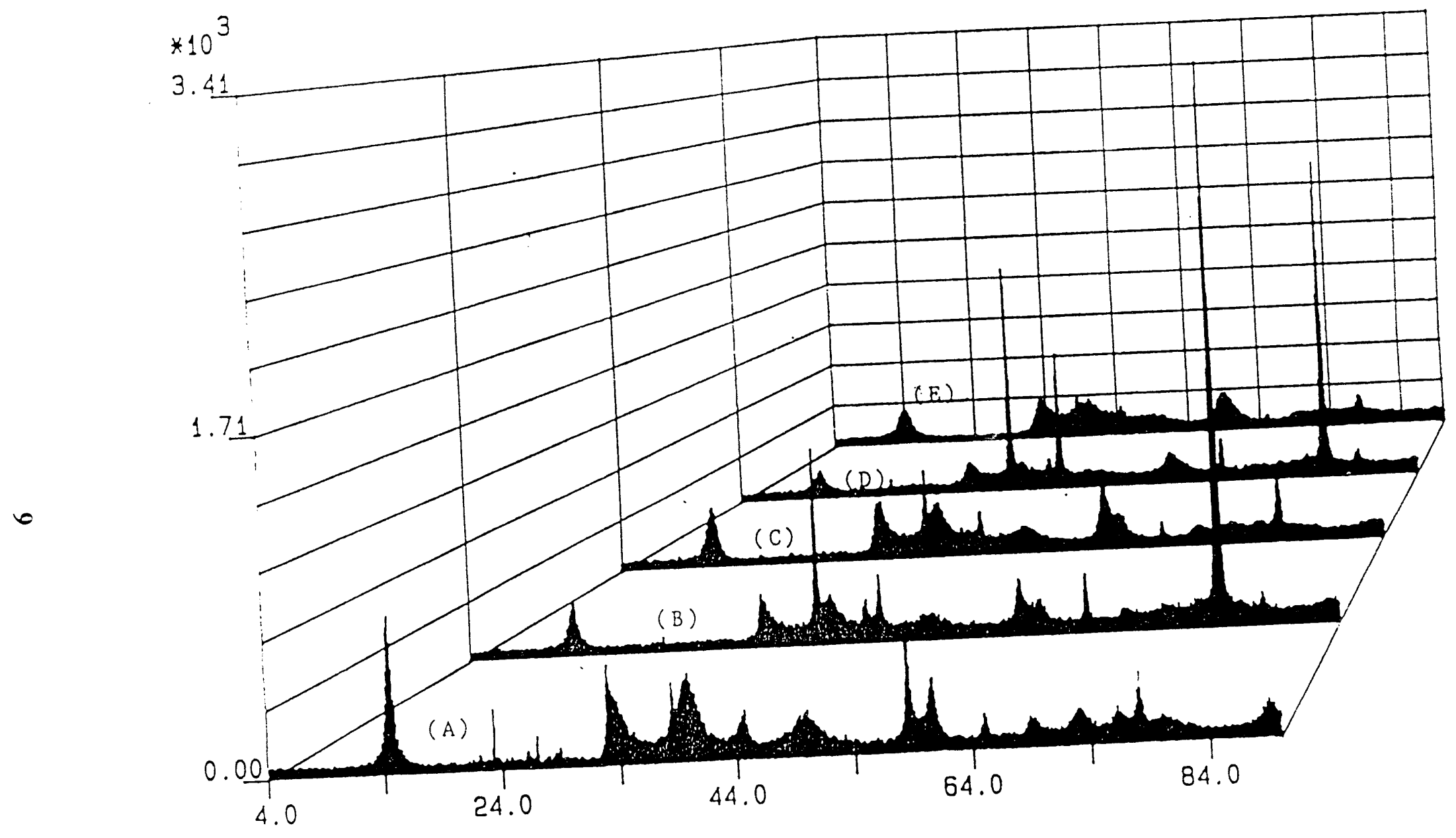

Figure $1.1 \mathrm{X}$-ray powder diffraction patterns of materials prepared by vapor phase reactions between $\mathrm{Mo}(\mathrm{CO})_{6}$ and $\mathrm{H}_{2} \mathrm{~S}$ Figure $1.1 \mathrm{X}$-ray powder diffraction patterns of materials prepared by vapor phase reactions betw en indexed to hexagonal $\mathrm{MoS}_{2}$. 


\section{TASK 2. PROCESS SYNTHESIS AND EVALUATION}

\subsection{Introduction}

During the past quarter, the fifth and six base cases, involving the Shell gasifier, have been completed. Furthermore, all six base cases have been scaled-up in order to determine whether economies of scale exist.

Refinements of the preliminary scale up analysis have been made in accordance with the needs discussed in the Second Quarter report of 1993. While these simple scaling factors provide a general indication as to the economic feasibility of the various gasifier technologies, they fail to reflect the true production or gate cost of the mixed alcohol product. Therefore, these general scaling factors have been replaced with more accurate representations.

In addition, the foundation for process opiimization is still being developed and a preliminary investigation of the concept of an energy park has begun.

\subsection{Accomplishments, Results and Discussion}

\subsubsection{Target Blends}

To provide a production goal for the designs, target products are necessary. All fuels for light-duty gasoline vehicles must be certified by EPA. Two blends already certified (i.e., granted waivers) that are closest to our projected product are the DuPont blend $(1,2)$ and OCTAMIX ${ }^{\text {ru }}-(3)$. These blends contain $<5$ vol \% methanol and $>2.5$ vol \% higher alcohols $\left(C_{2}-C_{4}\right.$ for DuPont, $C_{2}-C_{8}$ for OCTAMIX $\left.{ }^{\text {rx }}\right)$ plus $40 \mathrm{mg} / \mathrm{I}$. of a corrosion inhibitor necessitated because water is soluble enough in methanol to corrode automobile gasoline distribution systems. The products to be developed in this project are similar to these blends. For these blends, little or no purification of the alcohol synthesis reactor product is necessary.

A method using MTBE as a reference has been used to assign values to higher alcohol fuel products. The method is based upon RVP, octane number and oxygen content, and has been used previously to determine the value of ether fuel additives (4). The results are presented in Table 2.1. With these values available, it is now possible to estimate a return on investment for a coal to alcohol fuels plant.

For these calculations, we assumed blending for an RVP of 7.2 psia, a price for unloaded regular gasoline (87 octane) of $\$ 0.65 / \mathrm{gal}$, a price for $\mathrm{n}$-butane of $\$ 0.39 / \mathrm{gal}$, and an incremental value for octane enhancement of $\$ 0.0075 /$ gallon-octane-number. For the value of the oxygen enhancement provided by the additives, we assumed a linear relationship that was consistent with a price for MTBE of $\$ 0.95 / \mathrm{gal}$. 
Table 2.1

Estimated Value of Alcohol Fuel Additives

Component

methanol

ethanol

propanol

butanol

pentanol

mixed alcohol product*

MTBE
Blending Value (\$/gal)

0.98

1.13

0.91

0.86

0.83

1.03

0.95

*value obtained based upon base case product distribution from alcohol synthesis reactor

\subsubsection{Base Case Designs}

The flow sheet and stream tables for Base Cases 5 and 6 are included in the Appendix. Base Case 5 uses a Shell gasifier with a sour gas shift converter whereas Base Case 6 uses a Shell gasifier with natural gas.

To review the procedure for process economic analysis, the prices assumed for reactants, products and by-products are shown in Table 2.2. It was assumed that all by-products such as sulfur and slag could be sold at the indicated price.

\begin{tabular}{|cc|}
\hline \multicolumn{2}{c|}{ Table 2.2 } \\
Price of Reactants, Products and By-products \\
Item & Price \\
& \\
Coal & $\$ 33 /$ metric ton delivered \\
Power & $\$ 0.05 / \mathrm{kw}-\mathrm{hr}$ \\
Slag & $\$ 5.5 /$ metric ton \\
Sulfur & $\$ 300 /$ metric ton \\
Natural Gas & $\$ 100 / 1000 \mathrm{std} \mathrm{m}^{3}$ \\
\hline
\end{tabular}

No price is indicated for the alcohol fuel product. Instead, the cost of production of the product was calculated for various pay back periods.

For the initial base case designs, one unit train of coal (" $10^{4}$ tons) per week (1400 tons/day), was assumed. This is about 7-8 times less lhan the amount of coal used by a typical full-scale 
power plant, and a reasonable minimum size plant to consider. For the purposes of discussion, we are assuming that this coal to alcohol fuels plant would be located somewhere in southern West Virginia. If these initial base case designs were scaled-up by a factor of $8,32 \mathrm{MM}$ bbl/year of alcohol fuel additive would be produced, which is about $10 \%$ of the total gasoline sold in a seven state area surrounding West Virginia. This scale seems a reasonable upper limit on plant size if the alcohol fuel is to be used as an additive comprising $<10$ vol $\%$ in gasoline. Finally, assuming the same plant location, 8 unit trains of coal per week represents the output of three of the largest mines in West Virginia. The facility must be located near mines of this size so that transportation costs do not inflate the cost of coal so much that the alcohol fuel becomes too expensive.

Economies of scale have been investigated for all of the base cases, as described in the next section. Table 2.3 summarizes the six base cases. Table 2.4 summarizes the capital, operating and by-product costs for all of the base cases. Figure 2.1 shows the price of alcohol fuel product for all of the base cases, at $4 \mathrm{MM} \mathrm{bbl/yr} \mathrm{alcohol} \mathrm{fuel} \mathrm{production,} \mathrm{as} \mathrm{a} \mathrm{function} \mathrm{of}$ payback period. Since we are unsure at this time as to the fate of excess hydromen in the natural gas base case, two limiting cases have been considered. Base case 3 assumes that excess hydrogen has no value, whereas Base Case $3 \mathrm{H}$ assumes that excess hydrogen is sold as merchant grade, for $\$ 1.74 / 1000 \mathrm{ft}^{3}$.

It is clear from Figure 2.1 that natural gas is superior to coal as a source of alcohol fuels if excess hydrogen can be sold or used internally as a fuel. However, further examination of Figure 2.1 shows that, at a mixed alcohol fuel additive price of $\$ 1.03 /$ gal, the best payback period for coal derived product is about 6.5 years, which is equivalent to a $14 \% \mathrm{ROI}$, based on a plant life of 20 years, without considering the effects of inflation or taxes.

\begin{tabular}{|c|c|c|}
\hline \multicolumn{3}{|c|}{$\begin{array}{c}\text { Table } 2.3 \\
\text { Summary of Base Case Designs }\end{array}$} \\
\hline Base Case Number & Gasifier & $\mathrm{H}_{2} / \mathrm{CO}$ adjustment \\
\hline 1 & Texaco & $\begin{array}{l}\text { steam reforming } \\
\text { of natural gas }\end{array}$ \\
\hline 2 & Lurgi & $\begin{array}{l}\text { steam reforming } \\
\text { of natural gas }\end{array}$ \\
\hline 3 & None (Natural Gas only) & $\begin{array}{l}\text { PSA to separate } \\
\text { excess } \mathrm{H}_{2}\end{array}$ \\
\hline 4 & Texaco & sour gas shift converter \\
\hline 5 & Shell & sour gas shift converter \\
\hline 6 & Shell & $\begin{array}{l}\text { steam reforming } \\
\text { of natural gas }\end{array}$ \\
\hline
\end{tabular}



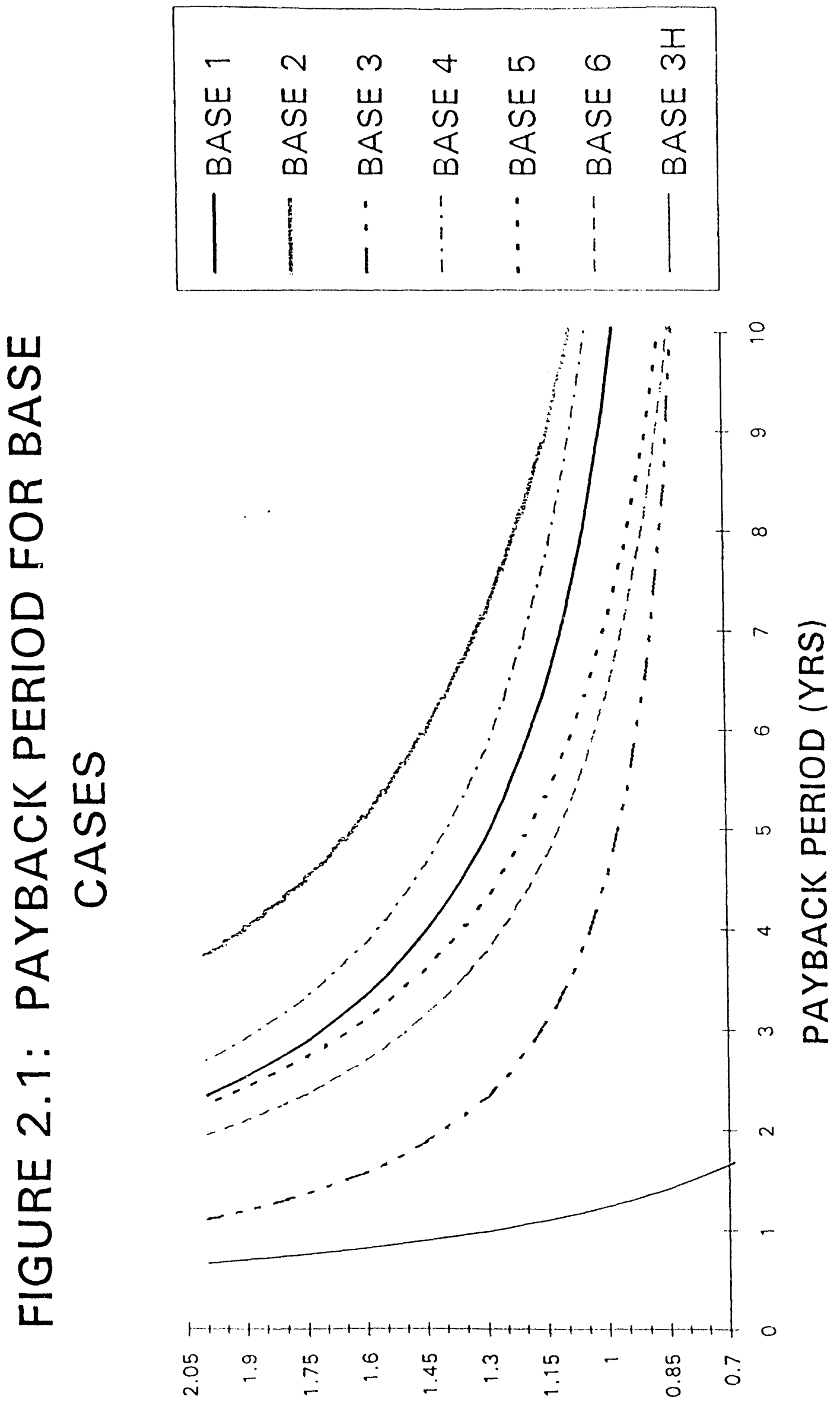

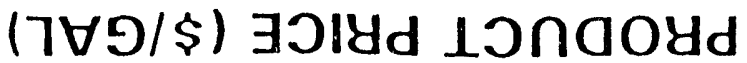




\begin{tabular}{|c|c|c|c|c|}
\hline \multicolumn{5}{|c|}{$\begin{array}{c}\text { Table } 2.4 \\
\text { Summary of Costs for Base Cases }\end{array}$} \\
\hline Base Case & $\begin{array}{c}\text { Alcohol } \\
\text { Production } \\
\text { (MM bbl/yr) }\end{array}$ & $\begin{array}{l}\text { Capital Cost } \\
\text { (MM\$) }\end{array}$ & $\begin{array}{c}\text { Operating } \\
\text { Cost } \\
(\mathbf{M M} \$ \mathbf{y r})\end{array}$ & $\begin{array}{l}\text { By-Product } \\
\text { Credits } \\
\text { (MM\$/yr) }\end{array}$ \\
\hline \multirow[t]{4}{*}{1} & 4 & 532.8 & 133.9 & 22.2 \\
\hline & 8 & 955.3 & 267.8 & 44.4 \\
\hline & 16 & $1,757.8$ & 535.6 & 88.8 \\
\hline & 32 & $3,291.6$ & $1,071.2$ & 177.6 \\
\hline \multirow[t]{4}{*}{2} & 4 & 931.5 & 236.9 & 146.6 \\
\hline & 8 & $1,734.3$ & 473.8 & 293.2 \\
\hline & 16 & $3,276.7$ & 947.6 & 586.4 \\
\hline & 32 & $6,212.3$ & 1895.2 & $1,172.8$ \\
\hline \multirow[t]{4}{*}{3} & 4 & 248.3 & 144.5 & 29.5 \\
\hline & 8 & 409.2 & 289.0 & 59.0 \\
\hline & 16 & 691.4 & 578.0 & 118.0 \\
\hline & 32 & $1,191.7$ & 1156.0 & 236.0 \\
\hline $3 \mathrm{H}$ & 4 & 248.3 & 144.5 & 175.0 \\
\hline \multirow[t]{4}{*}{4} & 4 & 600.8 & 135.6 & 18.8 \\
\hline & 8 & $1,062.7$ & 271.2 & 37.6 \\
\hline & 16 & $1,981.4$ & 542.4 & 75.2 \\
\hline & 32 & $3,713.0$ & $1,084.8$ & 150.4 \\
\hline \multirow[t]{4}{*}{5} & 4 & 568.6 & 132.8 & 44.0 \\
\hline & 8 & 975.2 & 265.6 & 88.0 \\
\hline & 16 & $1,822.3$ & 531.2 & 176.0 \\
\hline & 32 & $3,398.9$ & $1,062.4$ & 352.0 \\
\hline \multirow{4}{*}{6} & 4 & 484.0 & 123.9 & 30.0 \\
\hline & 8 & 832.4 & 247.8 & 60.0 \\
\hline & 16 & $1,418.6$ & 495.6 & 120.0 \\
\hline & 32 & $2,556.4$ & 991.2 & 240.0 \\
\hline
\end{tabular}




\subsubsection{Scale Up}

Replacement of the general scaling exponent with actual scaled up costs for the various components had little effect on the overall ranking of the various technologies; however, it did substantially impact their derived gate cost. Preliminary gate cost figures derived from the model using the simple scaling exponent of 0.7 where understated. Thus the economic status of the proposed mixed alcohol oxygenate needs to be reinvestigated before any formal conclusions can be made with regard to its economics.

Currently, the plarit gate costs are derived from a modification of the basic spread sheet model developed to calculate the production cost of syngas. This model simply amortizes the installed capital investment over the anticipated life of the plant which in this case is assumed to be twenty years at a given interest rate which we have assumed to be ten percent given current economic conditions. This yields an annuity which is then add to the raw materials and operating costs to get a total production cost. The operating cost are assumed to include maintenance, insurance and taxes, plant overhead and depreciation. These cost are estimated to be approximately 17.6 percent of the total installed capital or 1.5 time the annualized capital investment. Any by-product credits must then be subtracted to derive the final plant gate cost of the mixed alcohol product.

The results of the scale-up calculation are shown in Figure 2.2. An increase in plant capacity makes a Shell gasifier with natural gas the most attractive case. Furthermore, the economic advantages of a Shell gasifier over a Texaco or Lurgi gasifier are clear. There are also economies of scale; however, they diminish above a $32 \mathrm{MM} \mathrm{bbl/yr}$ plant capacity. The plant gate costs in Figure 2.2 represent a $10 \%$ return of capital over a 20 year plant life without considering the effects of taxes or inflation.

\subsubsection{Optimization}

Optimization requires detailed data relating the cost of equipment as a function of temperature and pressure. This procedure is being developed on the alcohol synthesis and separation section of the process.

The alcohol separation system produces a number of products which can be used as gasoline blends. This section consists of a sequence of distillation columns which perform the required separation of the stream coming out of the reactor into appropriate products. The thermodynamic package used for the design of the distillation columns has been provided by Union Carbide. The thermodynamic package, when used with ASPEN, gives appropriate results for rigorous distillation column design and suitable costs can be obtained for the network of the columns performing the appropriate separation.

The cost of a distillation column is dependent on a number of variables. The variables that are considered for this work are the pressure at the top and bottom of the column, temperature 


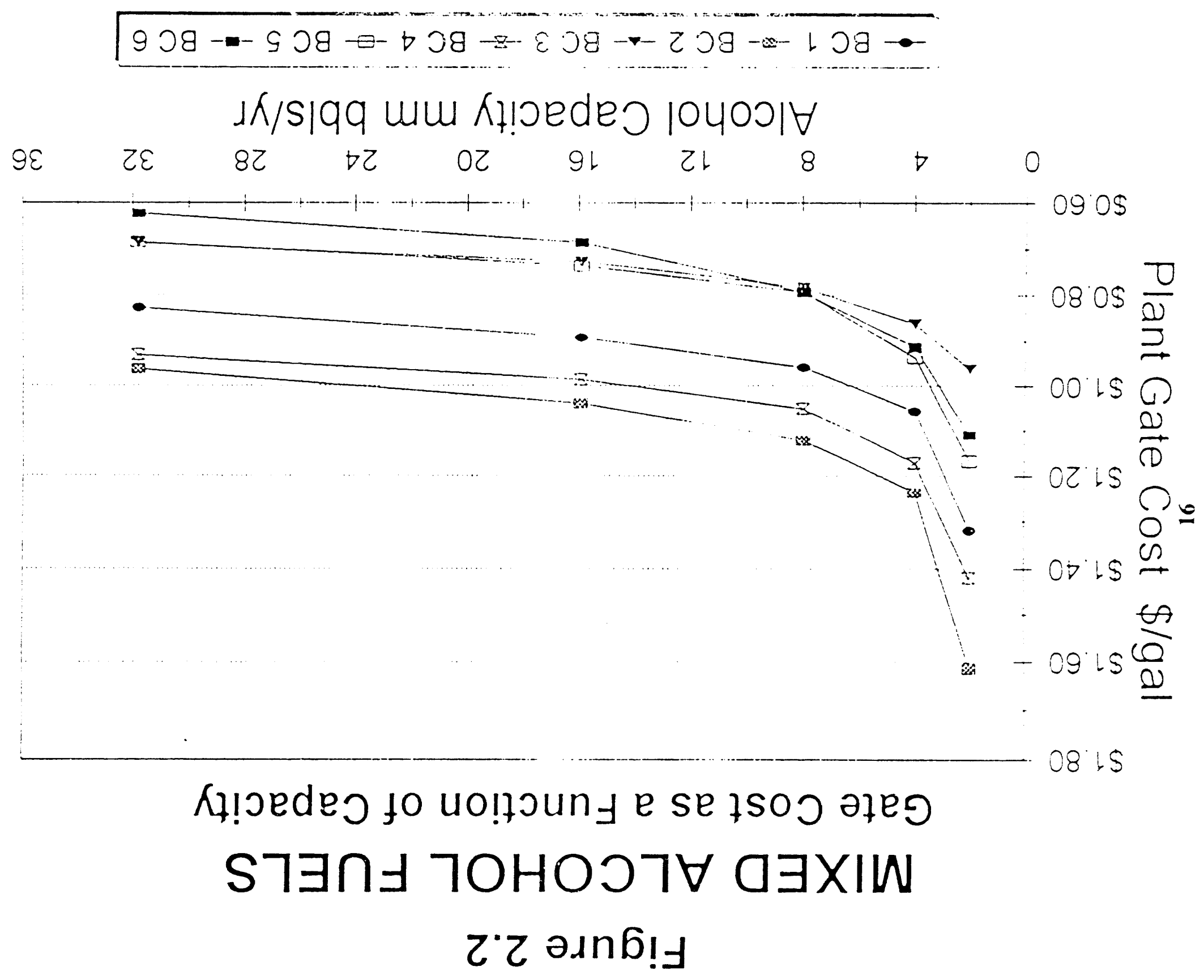


of the feed, the degree of separation of the light and heavy key, the relative composition of the various components in the feed stream, the volumetric flow of the feed stream, the number of stages and the feed stage location. As it is very difficult to generate cost data for each variable, a case study is done to find the appropriate feed stage location for a fixed number of stages. It is also observed that the feed stage location has the least effect on the cost of the column for a fixed number of stages. For each problem as the number of stages is increased, the installed cost comprising the distillation column, condenser and the reboiler cost goes up while the operating cost comprising the hot and cold utilities goes down. Thus, a case study is done for varying number of stages to locate the minimum cost of performing the required separation. In all, 40 problems are randomly generated for each different separation to be considered and the cost obtained by performing rigorous separation using ASPEN Plus and its costing model. For each problem, the cost is generated for 5 different number of stages to locate the appropriate stage with minimum cost for that particular separation. The cost data are then regressed over an equation to represent the cost of separation in terms of the various variables considered. To test the quality of the equation obtained, 10 additional problems are randomly generated and the cost for each problem is obtained, both from ASPEN and the regressed equation. It is observ'd that the deviation of the cost from the regressed equations from the cost obtained by using ASPEN is less than $10 \%$ for each case.

Simulated annelling will be used to perform the optimization of the reactor and the separation system considered simultaneously. At present, the computer code for the optimization problem is being programmed. Additional data, if required, will be generated for costing of the reactor or the distillation columns.

\subsubsection{Energy Park}

By definition, an energy park is a combination of facilities that utilizes one or more types of fuel in one or more types of conversion technologies to produce more than one product with the goal of reducing costs through the production of by-products, increased energy efficiency, and reduced pollution. The technologies, fuel and pollution problems related to producing coalbased alcohol fuels are highly amenable to being included in an energy park. This means all types of fuels, including coal and natural gas, should be considered as inputs, as in Base Cases 1 and 6. Also, more than one type of technology, including high and low temperature gasification, should be considered. In addition, the co-production of power, alcohol fuel, coal chemicals, and useful steam must be considered as a means to increase energy utilization efficiencies and to decrease overall costs.

If energy is used more efficiently, not only are costs lessened, but pollution is also reduced. For example, a conventional steam-electric generation plant converts only 35 percent of the energy in coal to usable electric energy. The remainder is lost. For the quantity of power produced, a proportional amount of pollutants are also produced. It has been demonstrated that if the energy in the waste heat is captured, an overall efficiency of 85 percent can be achieved. Such an increase in efficiency would result in nearly a 60 percent decline in pollution per usable energy unit output. 
Initial economics suggest that coal gasification using Lurgi technology, which is capable of producing a wide range of coal derived chemical feed stocks, will not be economic even under highly optimistic assumptions. On the other hand, high temperature Shell and Texaco gasifiers, which appear to have the most promise for the economical production of coal derived syngas, produce few coal by-products. Since the availability of chemical feed stocks would be advantageous in the operation of an energy park, it might be feasible to have both high and low temperature gasifiers in operation at an energy park producing a wide range of energy products. Such a low temperature gasifier may be of a design with lower capital per unit output requirements, such as the Chemcoke process, rather than a Lurgi plant.

A variety of types of fuel may be economically used in an energy park, not just coal. Natural gas can be easily and effectively used to reduce the excess $\mathrm{CO}_{2}$ to syngas in the Shell gasification process. Low Btu coal bed methane or methane from sanitary landfills could also be used as energy sources. Other organic wastes, such as grain wastes, wood products, or solid municipal waste, could also be used as fuel sources in such a complex.

Since the evaluation of the feasibility of an energy park is complex, the identification of key indicators may be of help in selecting a feasible combination of technologies, feed stocks, and products. One key indicator may be that the total installation have a high overall energy utilization rate. For example, any combination of technologies, inputs, and outputs that does not result in an overall energy efficiency of 75 to 80 percent might be rejected. It is unlikely that any facility that is not highly efficient in energy utilization will be economic given alternative technologies that exists and the highly competitive nature of energy conversions. In addition, an inefficient user of energy, even if presently economical, will probably not be economic in the future with increasing energy prices and environmental cost. Therefore, having a requirement of high energy efficiency appears to be a reasonable screening mechanism to supplement straight forward economic evaluations.

The Energy Park concept will be in the forefront of future optimization studies.

\subsection{Conclusions and Recommendations}

There are significant differences between the payback periods and production costs for processes converting coal to syngas to higher alcohol fuel additives for cases involving Texaco, Lurgi and Shell gasifiers, between cases involving natural gas reforming or sour gas shift conversion to alter the $\mathrm{H}_{2} / \mathrm{CO}$ ratio, and for different plant capacities.

Production of $32 \mathrm{MM} \mathrm{bbl} / \mathrm{yr}$ of alcohol fuels from coal is considered the maximum feasible process scale. As expected, there are economies of scale favoring larger-scale over smaller-scale processes. However, there appear to be diminishing economies of scale above this plant size.

A reasonable price for mixed alcohol product is $\$ 1.03 / \mathrm{gal}$, which is calculated by comparison of appropriate properties relative to MTBE. At this price, the estimated best case payback 
period is for a Shell gasifier with natural gas and is 6.5 years, which corresponds to a return on investment of $14 \%$, without consideration of taxes and inflation.

Production of higher alcohol fuel additives from natural gas is more economical at any scale at current or predicted natural gas prices if excess hydrogen can be sold or used internally as a fuel. For a $10 \%$ discount rate, at $4 \mathrm{MM} \mathrm{bbl/yr}$, natural gas is more economical even if excess hydrogen is assumed to have no value.

The potential exists for an integrated approach to produce mixed alcohols given the various technologies currently under consideration. Each technology has it own strengths and weakness; by taking advantage of the strengths of these various technologies the overall economics of alcohol production may be improved. This integration may be achieved in the context of an energy park as described in the previous section.

\subsection{Future Plans}

Now that the base case analyses are complete, the focus will turn to optimization and energy park.

\subsection{Appendix 1 for Task 2}

Appendix 1 contains the flow sheet and stream summaries for Base Cases 5 and 6 . Figures 2.3 and 2.4 are the flow sheets and Tables 2.5 and 2.6 are the stream summaries.

\subsection{References for Task 2}

1. 51 FR 39800 [Federal Register, \#39800 (1986)].

2. 52 FR 18736 [Federal Register, \#18736 (1987)].

3. 53 FR 43768 [Federal Register, \#43768 (1988)].

4. Rock, K. L., T. de Cardenas and L. Fornoff, "The New Refinery Challenge," Fuel Reformulation, Nov/Dec, 1992, p. 42. 
Rev. O] $8 / 7 / 83$ Rev.1 $8 / 16 / 83$

Figure 2.3 BASE CASE \# 5

$4+\ldots$

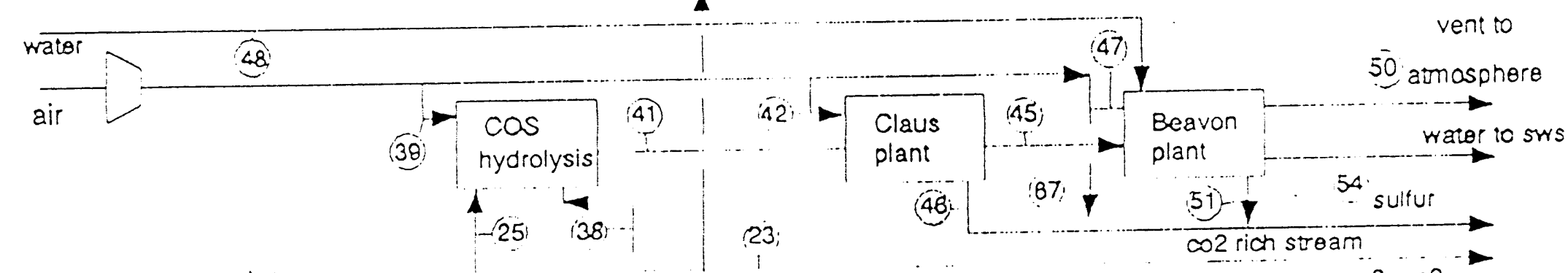

$\stackrel{N}{0}$
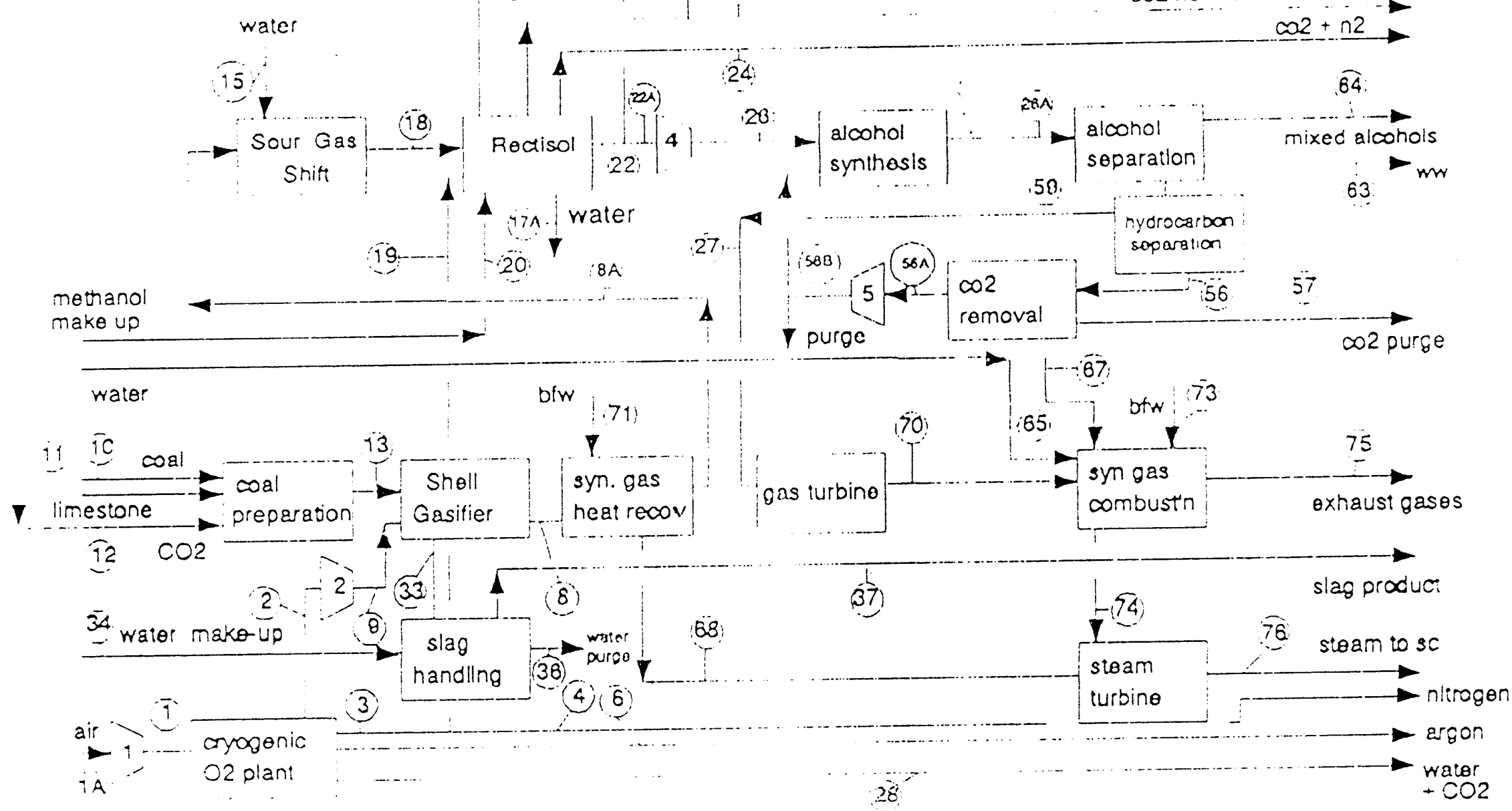


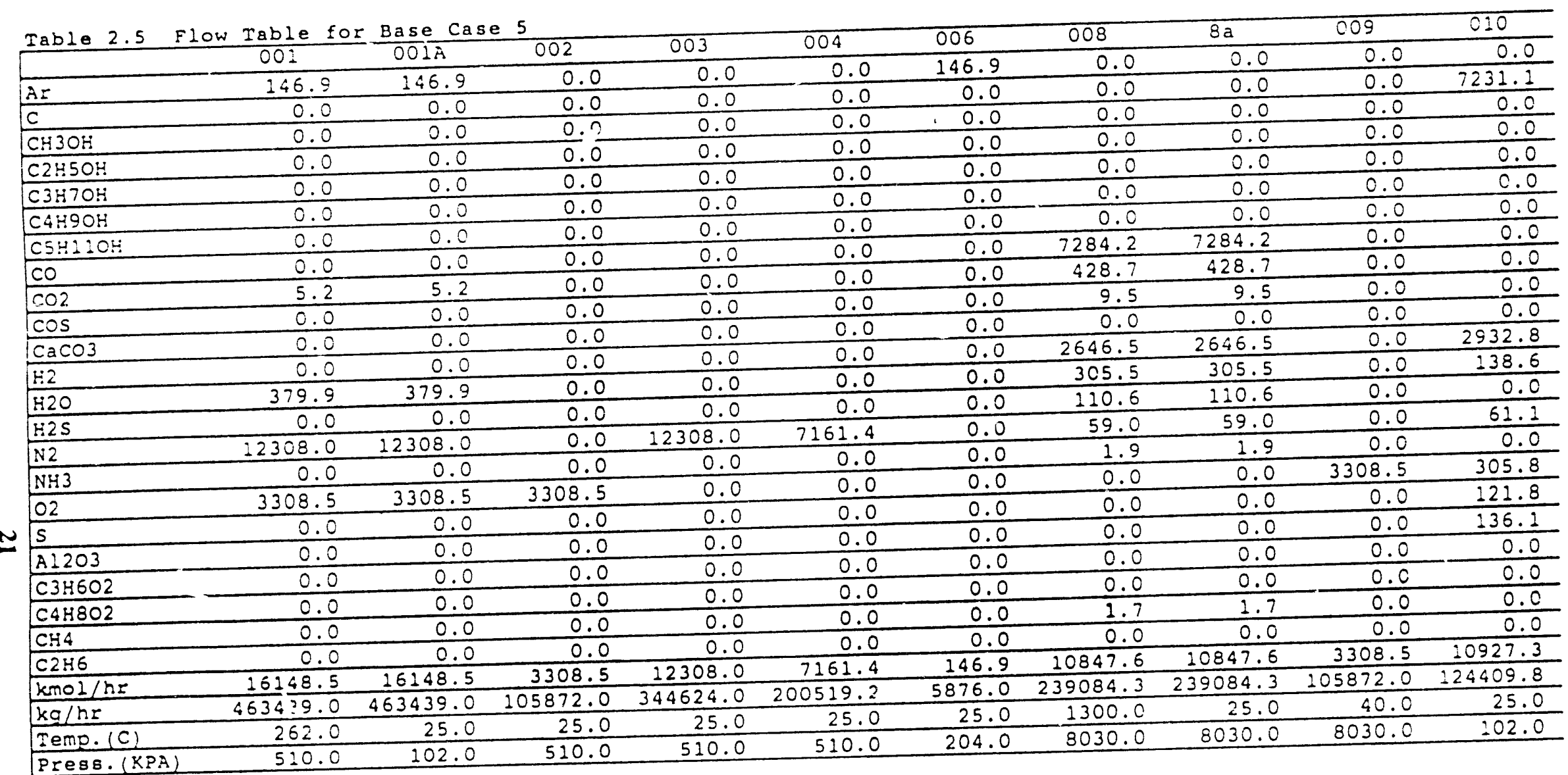


Table 2.5 (cont.)

\begin{tabular}{|c|c|c|c|c|c|c|c|c|}
\hline 11 & 013 & $017 A$ & 018 & 019 & 020 & 022 & $022 A$ & 023 \\
\hline 0.0 & 0.0 & 0.0 & 0.0 & 0.0 & 0.0 & 0.0 & 0.0 & 0.0 \\
\hline 0.0 & 7231.1 & 0.0 & 0.0 & 0.0 & 0.0 & 0.0 & 0.0 & 0.0 \\
\hline 0.0 & 0.0 & 0.0 & 0.0 & 0.0 & 18.0 & 0.0 & 0.0 & 0.0 \\
\hline 0.0 & 0.0 & 0.0 & 0.0 & 0.0 & 0.0 & 0.0 & 0.0 & 0.0 \\
\hline 0.0 & 0.0 & 0.0 & 0.0 & 0.0 & 0.0 & 0.0 & 0.0 & 0.0 \\
\hline 0.0 & 0.0 & 0.0 & 0.0 & 0.0 & 0.0 & 0.0 & 0.0 & 0.0 \\
\hline 0.0 & 0.0 & 0.0 & 0.0 & 0.0 & 0.0 & 0.0 & 0.0 & 0.0 \\
\hline 0.0 & 0.0 & 0.0 & 4672.7 & 0.0 & 0.0 & 4672.7 & 4625.9 & 0.0 \\
\hline 0.0 & 544.7 & 0.0 & 3040.2 & 0.0 & 0.0 & 0.0 & 0.0 & 1824.1 \\
\hline 0.0 & 0.0 & 0.0 & 9.5 & 0.0 & 0.0 & 0.0 & 0.0 & 0.0 \\
\hline 5.9 & 5.9 & 0.0 & 0.0 & 0.0 & 0.0 & 0.0 & 0.0 & 0.0 \\
\hline 0.0 & 2932.8 & 0.0 & 5258.0 & 0.0 & 0.0 & 5258.0 & 5205.4 & 0.0 \\
\hline 0.0 & 138.6 & 2306.0 & 2306.0 & 0.0 & 0.0 & 0.0 & 0.0 & 0.0 \\
\hline 0.0 & 0.0 & 0.0 & 110.6 & 0.0 & 0.0 & 0.0 & 0.0 & 0.0 \\
\hline 0.0 & 61.1 & 0.0 & 59.0 & 5146.7 & 0.0 & 0.0 & 0.0 & 0.0 \\
\hline 0.0 & 0.0 & 0.0 & 1.9 & 0.0 & 0.0 & 0.0 & 0.0 & 0.0 \\
\hline 0.0 & 305.8 & 0.0 & 0.0 & 0.0 & 0.0 & 0.0 & 0.0 & 0.0 \\
\hline 0.0 & 121.8 & 0.0 & 0.0 & 0.0 & 0.0 & 0.0 & 0.0 & 0.0 \\
\hline 0.0 & 136.1 & 0.0 & 0.0 & 0.0 & 0.0 & 0.0 & 0.0 & 0.0 \\
\hline 0.0 & 0.0 & 0.0 & 0.0 & 0.0 & 0.0 & 0.0 & 0.0 & 0.0 \\
\hline 0.0 & 0.0 & 0.0 & 0.0 & 0.0 & 0.0 & 0.0 & 0.0 & 0.0 \\
\hline 0.0 & 0.0 & 0.0 & 1.7 & 0.0 & 0.0 & 1.7 & 1.7 & 0.0 \\
\hline 0.0 & 0.0 & 0.0 & 0.0 & 0.0 & 0.0 & 0.0 & 0.0 & 0.0 \\
\hline 5.9 & 11477.9 & 2306.0 & 15459.6 & 5146.7 & 18.0 & 9932.4 & 9833.0 & 1824.1 \\
\hline 90.0 & 148966.6 & 41508.0 & 322100.3 & 144107.6 & 576.0 & 141378.8 & 139963.2 & 80260.4 \\
\hline 25.0 & 25.0 & 25.0 & 300.0 & 25.0 & 25.0 & 25.0 & 25.0 & 25.0 \\
\hline 02.0 & 8030.0 & 8030.0 & 80.30 .0 & 526.0 & 102.0 & 3030.0 & 8030.0 & 102.0 \\
\hline
\end{tabular}


Table 2.5 (cont.)

\begin{tabular}{|c|c|c|c|c|c|c|c|c|c|c|}
\hline & 024 & 025 & 026 & $026 \mathrm{~A}$ & 027 & 028 & 033 & 034 & 036 & 037 \\
\hline Ar & 0.0 & 0.0 & 0.0 & 0.0 & 0.0 & 0.0 & 0.0 & 0.0 & 0.0 & 0.0 \\
\hline$C$ & 0.0 & 0.0 & 0.0 & 0.0 & 0.0 & 0.0 & 49.3 & 0.0 & 0.0 & 49.3 \\
\hline $\mathrm{CH} 30 \mathrm{H}$ & 0.0 & 18.0 & 0.0 & 518.0 & 0.0 & 0.0 & 0.0 & 0.0 & 0.0 & 0.0 \\
\hline$C 2: G 0$ & 0.0 & 0.0 & 0.0 & 644.6 & 0.0 & 0.0 & 0.0 & 0.0 & 0.0 & 0.0 \\
\hline C3H8O & 0.0 & 0.0 & 0.0 & 142.7 & 0.0 & 0.0 & 0.0 & 0.0 & 0.0 & 0.0 \\
\hline $\mathrm{C} 4 \mathrm{H} 100$ & 0.0 & 0.0 & 0.0 & 35.9 & 0.0 & 0.0 & 0.0 & 0.0 & 0.0 & 0.0 \\
\hline C5:120 & 0.0 & 0.0 & 0.0 & 14.9 & 0.0 & 0.0 & 0.0 & 0.0 & 0.0 & 0.0 \\
\hline $\mathrm{CO}$ & 0.0 & 0.0 & 4625.9 & 6887.3 & 0.0 & 0.0 & 0.0 & 0.0 & 0.0 & 0.0 \\
\hline $\mathrm{CO2}$ & 1064.1 & 252.0 & 0.0 & $14^{\prime} 69.3$ & 0.0 & 5.8 & 0.0 & 0.0 & 0.0 & 0.0 \\
\hline $\cos$ & 0.0 & 9.5 & 0.0 & 0.0 & 0.0 & 0.0 & 0.0 & 0.0 & 0.0 & 0.0 \\
\hline $\mathrm{CaCO} 3$ & 0.0 & 0.0 & 0.0 & 0.0 & 0.0 & 0.0 & 5.9 & 0.0 & 0.0 & 5.9 \\
\hline $\mathrm{H2}$ & 0.0 & 0.0 & 5205.4 & 7824.7 & 0.0 & 0.0 & 0.0 & 0.0 & 0.0 & 0.0 \\
\hline 420 & 0.0 & 0.0 & 0.0 & 137.7 & 0.0 & 379.9 & 0.0 & 349.7 & 349.7 & 0.0 \\
\hline 425 & 0.0 & 110.6 & 0.0 & 0.0 & 0.0 & 0.0 & 0.0 & 0.0 & 0.0 & 0.0 \\
\hline $\mathrm{N} 2$ & 5205.7 & 0.0 & 0.0 & 0.0 & 0.0 & 0.0 & 0.0 & 0.0 & 0.0 & 0.0 \\
\hline $\mathrm{NH3}$ & 0.0 & 1.9 & 0.0 & 0.0 & 0.0 & 0.0 & 0.0 & 0.0 & 0.0 & 0.0 \\
\hline 02 & 0.0 & 0.0 & 0.0 & 0.0 & 0.0 & 0.0 & 0.0 & 0.0 & 0.0 & 0.0 \\
\hline$s$ & 0.0 & 0.0 & 0.0 & 0.0 & 0.0 & 0.0 & 1.7 & 0.0 & 0.0 & 1.7 \\
\hline A1203 & 0.0 & 0.0 & 0.0 & 0.0 & 0.0 & 0.0 & 136.1 & 0.0 & 0.0 & 136.1 \\
\hline $\mathrm{C} 3 \mathrm{H} 602$ & 0.0 & 0.0 & 0.0 & 17.8 & 0.0 & 0.0 & 0.0 & 0.0 & 0.0 & 0.0 \\
\hline C4.4802 & 0.0 & 0.0 & 0.0 & 11.7 & 0.0 & 0.0 & 0.0 & 0.0 & 0.0 & 0.0 \\
\hline C: 4 & 0.0 & 0.0 & 36.7 & 435.6 & 435.6 & 0.0 & 0.0 & 0.0 & 0.0 & 0.0 \\
\hline $\mathrm{C} 2 \mathrm{H} 6$ & 0.0 & 0.0 & 0.0 & 17.2 & 17.2 & 0.0 & 0.0 & 0.0 & 0.0 & 0.0 \\
\hline $\mathrm{kmol} / \mathrm{hr}$ & 6269.8 & 292.0 & 9868.0 & 18257.4 & 452.8 & 385.7 & 193.0 & 349.7 & 349.7 & 193.0 \\
\hline $\mathrm{kg} / \mathrm{hr}$ & 192580.0 & 11056.7 & 140523.2 & 347411.4 & 7485.6 & 7093.4 & 15113.2 & 6294.6 & 6294.6 & 25113.2 \\
\hline Temp. (c) & 25.0 & 25.0 & 310.0 & 310.0 & 50.0 & 25.0 & 1300.0 & 25.0 & 156.0 & $: 56.0$ \\
\hline Press. (KPA) & 102.0 & 102.0 & 14000.0 & 14030.0 & 20000.0 & 20.0 .0 & $8: 30.0$ & 3400.0 & 3400.0 & 102.0 \\
\hline
\end{tabular}


Table 2.5 (cont.)

\begin{tabular}{|c|c|c|c|c|c|c|c|c|c|c|}
\hline & 038 & 039 & 041 & 042 & 045 & 046 & 047 & 048 & 050 & $05:$ \\
\hline$A=$ & 0.0 & 0.0 & 0.0 & 0.0 & 0.0 & 0.0 & 0.0 & 0.0 & 0.0 & 0.0 \\
\hline$C$ & 0.0 & 0.0 & 0.0 & 0.0 & 0.0 & 0.0 & 0.0 & 0.0 & 0.0 & 0.0 \\
\hline $\mathrm{CH} 3 \mathrm{OH}$ & 0.0 & 0.0 & 18.0 & 0.0 & 18.0 & 0.0 & 0.0 & 0.0 & 18.0 & 0.0 \\
\hline $\mathrm{C} 2 \mathrm{H} 60$ & 0.0 & 0.0 & 0.0 & 0.0 & 0.0 & 0.0 & 0.0 & 0.0 & 0.0 & 0.0 \\
\hline C3H80 & 0.0 & 0.0 & 0.0 & 0.0 & 0.0 & 0.0 & 0.0 & 0.0 & 0.0 & 0.0 \\
\hline C4H100 & 0.0 & 0.0 & 0.0 & 0.0 & 0.0 & 0.0 & 0.0 & 0.0 & 0.0 & 0.0 \\
\hline $\mathrm{C} 5 \mathrm{H} 12 \mathrm{O}$ & 0.0 & 0.0 & 0.0 & 0.0 & 0.0 & 0.0 & 0.0 & 0.0 & 0.0 & 0.0 \\
\hline $\mathrm{CO}$ & 46.7 & 0.0 & 46.7 & 0.0 & 0.0 & 0.0 & 0.0 & 0.0 & 0.0 & 0.0 \\
\hline $\mathrm{CO2}$ & 0.0 & 0.0 & 152.0 & 0.0 & 152.0 & 0.0 & 0.0 & 0.0 & 152.0 & 0.0 \\
\hline $\cos$ & 0.0 & 0.0 & 0.0 & 0.0 & 0.0 & 0.0 & 0.0 & 0.0 & 0.0 & 0.0 \\
\hline $\mathrm{CaCO} 3$ & 0.0 & 0.0 & 0.0 & 0.0 & 0.0 & 0.0 & 0.0 & 0.0 & 0.0 & 0.0 \\
\hline H2 & 52.5 & 0.0 & 52.6 & 0.0 & 0.0 & 0.0 & 0.0 & 0.0 & 0.0 & 0.0 \\
\hline $\mathrm{H} 2 \mathrm{O}$ & 0.0 & 0.0 & 0.0 & 0.0 & 99.5 & 0.0 & 0.0 & 20.0 & 0.0 & 0.0 \\
\hline $\mathrm{H} 2 \mathrm{~S}$ & 0.0 & 0.0 & 120.1 & 0.0 & 12.0 & 0.0 & 0.0 & 0.0 & 0.0 & 0.0 \\
\hline N2 & 0.0 & 20.0 & 20.0 & 156.0 & 156.0 & 0.0 & 22.3 & 0.0 & 178.3 & 0.0 \\
\hline NH3 & 0.0 & 0.0 & 1.9 & 0.0 & 1.9 & 0.0 & 0.0 & 0.0 & 1.9 & 0.0 \\
\hline 02 & 0.0 & 8.0 & 8.0 & 55.9 & 6.1 & 0.0 & 6.0 & 0.0 & 6.6 & 0.0 \\
\hline$s$ & 0.0 & 0.0 & 0.0 & 0.0 & 0.0 & 108.0 & 0.0 & 0.0 & 0.0 & 12.0 \\
\hline$A 1203$ & 0.0 & 0.0 & 0.0 & 0.0 & 0.0 & 0.0 & 0.0 & 0.0 & 0.0 & 0.0 \\
\hline $\mathrm{C} 3 \mathrm{H} 602$ & 0.0 & 0.0 & 0.0 & 0.0 & 0.0 & 0.0 & 0.0 & 0.0 & 0.0 & 0.0 \\
\hline C4:1802 & 0.0 & 0.0 & 0.0 & 0.0 & 0.0 & 0.0 & 0.0 & 0.0 & 0.0 & 0.0 \\
\hline $\mathrm{CH} 4$ & 0.0 & 0.0 & 0.0 & 0.0 & 0.0 & 0.0 & 0.0 & 0.0 & 0.0 & 0.0 \\
\hline C2H: & 0.0 & 0.0 & 0.0 & 0.0 & 0.0 & 0.0 & 0.0 & 0.0 & 0.0 & 0.0 \\
\hline $\mathrm{kmol} / \mathrm{hr}$ & 99.3 & 28.0 & 419.3 & 211.9 & 445.5 & 108.0 & 28.3 & 20.0 & 356.8 & 12.0 \\
\hline $\mathrm{kg} / \mathrm{hr}$ & 1412.8 & 816.0 & 13608.5 & 6156.8 & 14058.5 & 3456.0 & 816.4 & 360.0 & 12499.9 & 384.0 \\
\hline Ienp. (c) & 25.0 & 25.0 & 25.0 & 25.0 & 370.0 & 370.0 & 25.0 & 25.0 & 370.0 & 25.0 \\
\hline Press. (KPE) & 8030.0 & 102.0 & 102.0 & 102.0 & 102.0 & 102.0 & 102.0 & 102.0 & 102.0 & 102.0 \\
\hline
\end{tabular}




\begin{tabular}{|c|c|c|c|c|c|c|c|c|c|c|}
\hline & 054 & 056 & 0562 & 0568 & 057 & 059 & 063 & 064 & 065 & 067 \\
\hline$\dot{a r}$ & 0.0 & 0.0 & 0.0 & 0.0 & 0.0 & 0.0 & 0.0 & 0.0 & 0.0 & 62.0 \\
\hline$c$ & 0.0 & 0.0 & 0.0 & 0.0 & 0.0 & 0.0 & 0.0 & 0.0 & 0.0 & 0.0 \\
\hline $\mathrm{CH} 30 \mathrm{H}$ & 0.0 & 0.0 & 0.0 & 0.0 & 0.0 & 0.0 & 0.0 & 522.6 & 0.0 & 0.0 \\
\hline C2H5O & 0.0 & 0.0 & 0.0 & 0.0 & 0.0 & 0.0 & 0.0 & 649.4 & 0.0 & 0.0 \\
\hline $\mathrm{C} 3 \mathrm{H8O}$ & 0.0 & 0.0 & 0.0 & 0.0 & 0.0 & 0.0 & 0.0 & 143.7 & 0.0 & 0.0 \\
\hline C4H100 & 0.0 & 0.0 & 0.0 & 0.0 & 0.0 & 0.0 & 0.0 & 36.2 & 0.0 & 0.0 \\
\hline C5:120 & 0.0 & 0.0 & 0.0 & 0.0 & 0.0 & 0.0 & 0.0 & 25.0 & 0.0 & 0.0 \\
\hline $\mathrm{CO}$ & 0.0 & 6937.9 & 6937.9 & 6937.9 & 0.0 & 6937.9 & 0.0 & 0.0 & 0.0 & 0.0 \\
\hline $\mathrm{CO} 2$ & 0.0 & 1480.1 & 0.0 & 0.0 & 1480.1 & 1480.1 & 0.0 & 0.0 & 0.0 & 0.0 \\
\hline $\cos$ & 0.0 & 0.0 & 0.0 & 0.0 & 0.0 & 0.0 & 0.0 & 0.0 & 0.0 & 0.0 \\
\hline $\mathrm{CaCO3}$ & 0.0 & 0.0 & 0.0 & 0.0 & 0.0 & 0.0 & 0.0 & 0.0 & 0.0 & 0.0 \\
\hline 1.2 & 0.0 & 7806.3 & 7806.3 & 7806.3 & 0.0 & 7806.3 & 0.0 & 0.0 & 0.0 & 0.0 \\
\hline 520 & 210.6 & 0.0 & 0.0 & 0.0 & 0.0 & 0.0 & 138.8 & 0.0 & 422.5 & 0.0 \\
\hline 325 & 0.0 & 0.0 & 0.0 & 0.0 & 0.0 & 0.0 & 0.0 & 0.0 & 0.0 & 0.0 \\
\hline $\mathrm{N2}$ & 0.0 & 0.0 & 0.0 & 0.0 & 0.0 & 0.0 & 0.0 & 0.0 & 0.0 & 4827.5 \\
\hline $\mathrm{NH3}$ & 0.0 & 0.0 & 0.0 & 0.0 & 0.0 & 0.0 & 0.0 & 0.0 & 0.0 & 0.0 \\
\hline 02 & 0.0 & 0.0 & 0.0 & 0.0 & 0.0 & 0.0 & 0.0 & 0.0 & 0.0 & 1242.0 \\
\hline$s$ & 0.0 & 0.0 & 0.0 & 0.0 & 0.0 & 0.0 & 0.0 & 0.0 & 0.0 & 0.0 \\
\hline A1203 & 0.0 & 0.0 & 0.0 & 0.0 & 0.0 & 0.0 & 0.0 & 0.0 & 0.0 & 0.0 \\
\hline C3H602 & 0.0 & 0.0 & 0.0 & 0.0 & 0.0 & 0.0 & 17.9 & 0.0 & 0.0 & 0.0 \\
\hline $\mathrm{C} 4 \mathrm{H802}$ & 0.0 & 0.0 & 0.0 & 0.0 & 0.0 & 0.0 & 11.8 & 0.0 & 0.0 & 0.0 \\
\hline $\mathrm{CH} 4$ & 0.0 & 0.0 & 0.0 & 0.0 & 0.0 & 473.8 & 0.0 & 0.0 & 0.0 & 0.0 \\
\hline $\mathrm{C} 246$ & 0.0 & 0.0 & 0.0 & 0.0 & 0.0 & 0.0 & 0.0 & 0.0 & 0.0 & 0.0 \\
\hline kmol/hr & 110.6 & 16224.3 & 14744.2 & 14744.2 & 1480.1 & 16698.1 & 168.5 & 2465.9 & 422.5 & $6: 32.6$ \\
\hline $\mathrm{kg} / \mathrm{hr}$ & 1990.8 & 274998.2 & 209873.8 & 209873.8 & 65124.4 & 282579.0 & 4861.4 & 62416.4 & 7605.0 & 279396.3 \\
\hline Semp. (C) & 370.0 & 310.0 & 310.0 & 310.0 & 25.0 & 310.0 & 25.0 & 25.0 & 25.0 & 25.0 \\
\hline Press.(KPA) & 102.0 & 12500.0 & 12500.0 & 14000.0 & 102.0 & 12500.0 & 102.0 & 102.0 & 202.0 & $: 02.0$ \\
\hline
\end{tabular}




\begin{tabular}{|c|c|c|c|c|c|c|}
\hline & 068 & 070 & 071 & 073 & 074 & 075 \\
\hline$A I$ & 0.0 & 0.0 & 0.0 & 0.0 & 0.0 & 32.0 \\
\hline$C$ & 0.0 & 0.0 & 0.0 & 0.0 & 0.0 & 0.0 \\
\hline $\mathrm{CH} 3 \mathrm{OH}$ & 0.0 & 0.0 & 0.0 & 0.0 & 0.0 & 0.0 \\
\hline $\mathrm{C} 2 \mathrm{H} 6 \mathrm{O}$ & 0.0 & 0.0 & 0.0 & 0.0 & 0.0 & 0.0 \\
\hline C3H8O & 0.0 & 0.0 & 0.0 & 0.0 & 0.0 & 0.0 \\
\hline C4H10O & 0.0 & 0.0 & 0.0 & 0.0 & 0.0 & 0.0 \\
\hline C5H12O & 0.0 & 0.0 & 0.0 & 0.0 & 0.0 & 0.0 \\
\hline $\mathrm{CO}$ & 0.0 & 0.0 & 0.0 & 0.0 & 0.0 & 0.0 \\
\hline $\mathrm{CO} 2$ & 0.0 & 0.0 & 0.0 & 0.0 & 0.0 & 508.5 \\
\hline $\cos$ & 0.0 & 0.0 & 0.0 & 0.0 & 0.0 & 0.0 \\
\hline $\mathrm{CaCO} 3$ & 0.0 & 0.0 & 0.0 & 0.0 & 0.0 & 0.0 \\
\hline 142 & 0.0 & 0.0 & 0.0 & 0.0 & 0.0 & 0.0 \\
\hline 1420 & 7500.0 & 0.0 & 7500.0 & 3100.0 & 3100.0 & 948.3 \\
\hline H2S & 0.0 & 0.0 & 0.0 & 0.0 & 0.0 & 0.0 \\
\hline N2 & 0.0 & 0.0 & 0.0 & 0.0 & 0.0 & 4827.6 \\
\hline $\mathrm{NH3}$ & 0.0 & 0.0 & 0.0 & 0.0 & 0.0 & 0.0 \\
\hline 02 & 0.0 & 0.0 & 0.0 & 0.0 & 0.0 & 283.7 \\
\hline$s$ & 0.0 & 0.0 & 0.0 & 0.0 & 0.0 & 0.0 \\
\hline A1203 & 0.0 & 0.0 & 0.0 & 0.0 & 0.0 & 0.0 \\
\hline $\mathrm{C} 3 \mathrm{H} 602$ & 0.0 & 0.0 & 0.0 & 0.0 & 0.0 & 0.0 \\
\hline $\mathrm{C} 4 \mathrm{H} 802$ & 0.0 & 0.0 & 0.0 & 0.0 & 0.0 & 0.0 \\
\hline CH4 & 0.0 & 435.6 & 0.0 & 0.0 & 0.0 & 0.0 \\
\hline $\mathrm{C} 2 \mathrm{H} 6$ & 0.0 & 17.3 & 0.0 & 0.0 & 0.0 & 0.0 \\
\hline $\mathrm{kmol} / \mathrm{hr}$ & 7500.0 & 452.9 & 7500.0 & 3100.0 & 3100.0 & 6600.1 \\
\hline $\mathrm{kg} / \mathrm{hr}$ & 135000.0 & 7488.6 & 135000.0 & 55800.0 & 55800.0 & 184974.6 \\
\hline Temp. (C) & 482.0 & 25.0 & 20.0 & 20.0 & 482.2 & 25.0 \\
\hline Press.(KPA) & 10300.0 & 102.0 & 10300.0 & 10300.0 & 10300.0 & 102.0 \\
\hline
\end{tabular}




\section{Figure 2.4 BASE CASE \# 6}

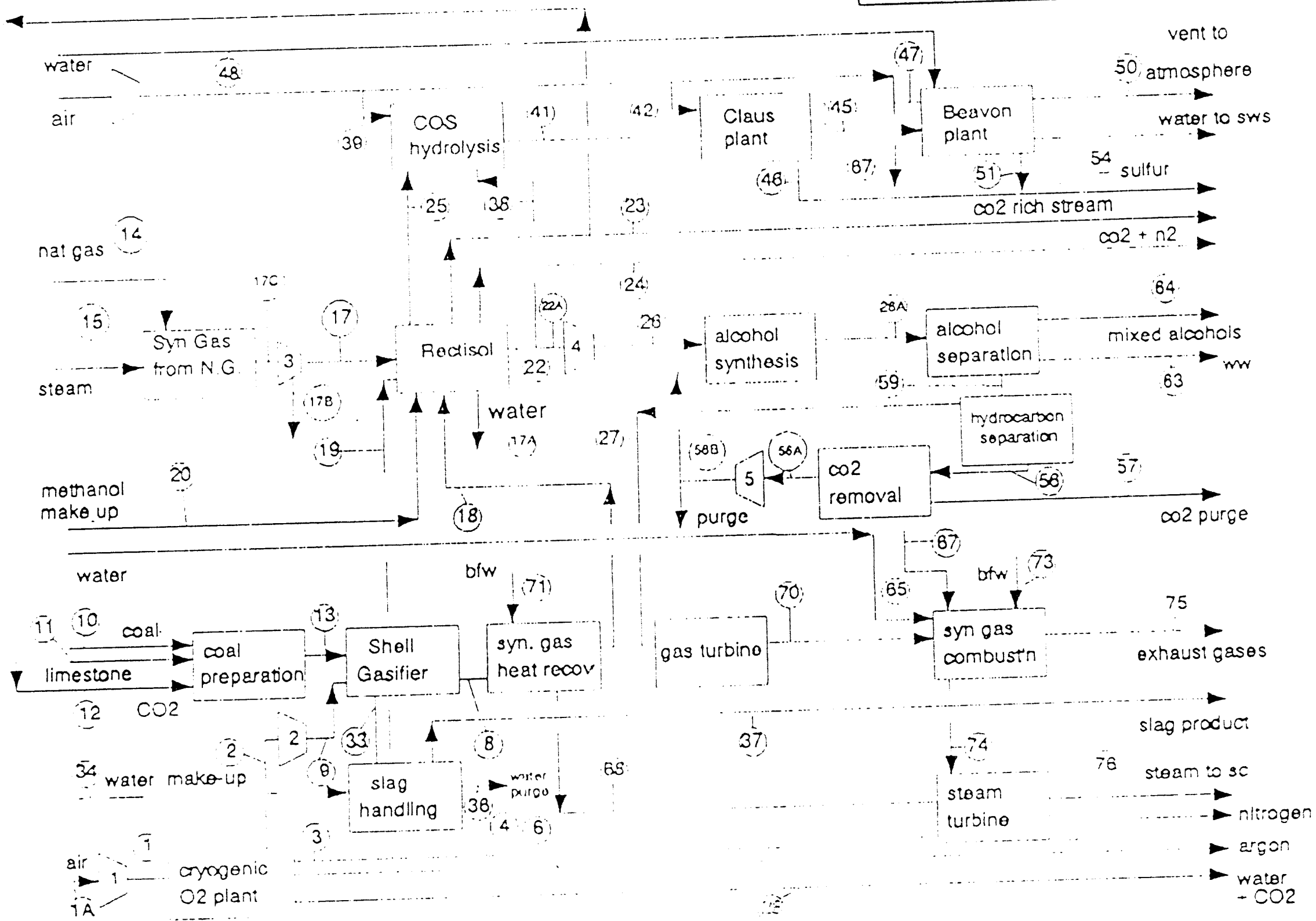


Table 2.6 Flow Table for Base Case 6

\begin{tabular}{|c|c|c|c|c|c|c|c|c|c|c|}
\hline & 001 & $001 A$ & 002 & 003 & 004 & 006 & 008 & 009 & 010 & $0: 2$ \\
\hline$A=$ & 73.4 & 73.4 & 0.0 & 0.0 & 0.0 & 73.4 & 0.0 & 0.0 & 0.0 & 0.0 \\
\hline $\mathrm{C}$ & 0.0 & 0.0 & 0.0 & 0.0 & 0.0 & 0.0 & 0.0 & 0.0 & 3613.7 & 0.0 \\
\hline $\mathrm{CH} 3 \mathrm{OH}$ & 0.0 & 0.0 & 0.0 & 0.0 & 0.0 & 0.0 & 0.0 & 0.0 & 0.0 & 0.0 \\
\hline $\mathrm{C} 2 \mathrm{H} 5 \mathrm{OH}$ & 0.0 & 0.0 & 0.0 & 0.0 & 0.0 & 0.0 & 0.0 & 0.0 & 0.0 & 0.0 \\
\hline $\mathrm{C} 3 \mathrm{H} 7 \mathrm{OH}$ & 0.0 & 0.0 & 0.0 & 0.0 & 0.0 & 0.0 & 0.0 & 0.0 & 0.0 & 0.0 \\
\hline $\mathrm{C} 4 \mathrm{H} 9 \mathrm{OH}$ & 0.0 & 0.0 & 0.0 & 0.0 & 0.0 & 0.0 & 0.0 & 0.0 & 0.0 & 0.0 \\
\hline C5H110: & 0.0 & 0.0 & 0.0 & 0.0 & 0.0 & 0.0 & 0.0 & 0.0 & 0.0 & 0.0 \\
\hline $\mathrm{CO}$ & 0.0 & 0.0 & 0.0 & 0.0 & 0.0 & 0.0 & 3638.4 & 0.0 & 0.0 & 0.0 \\
\hline $\mathrm{CO} 2$ & 0.0 & 0.0 & 0.0 & 0.0 & 0.0 & 0.0 & 217.3 & 0.0 & 0.0 & 0.0 \\
\hline $\cos$ & 0.0 & 0.0 & 0.0 & 0.0 & 0.0 & 0.0 & 4.8 & 0.0 & 0.0 & 0.0 \\
\hline $\mathrm{CaCO} 3$ & 0.0 & 0.0 & 0.0 & 0.0 & 0.0 & 0.0 & 0.0 & 0.0 & 0.0 & 2.9 \\
\hline $\mathrm{H2}$ & 0.0 & 0.0 & 0.0 & 0.0 & 0.0 & 0.0 & 1322.4 & 0.0 & 1465.6 & 0.0 \\
\hline 820 & 189.7 & 189.7 & 0.0 & 0.0 & 0.0 & 0.0 & 152.8 & 0.0 & 69.3 & 0.0 \\
\hline $52 S$ & 0.0 & 0.0 & 0.0 & 0.0 & 0.0 & 0.0 & 55.3 & 0.0 & 0.0 & 0.0 \\
\hline $\mathrm{N2}$ & 6146.8 & 6146.8 & 0.0 & 6146.8 & 6146.8 & 0.0 & 29.4 & 0.0 & 30.5 & 0.0 \\
\hline $\mathrm{NH3}$ & 0.0 & 0.0 & 0.0 & 0.0 & 0.0 & 0.0 & 1.0 & 0.0 & 0.0 & 0.0 \\
\hline 02 & 1652.5 & 1652.5 & 1652.5 & 0.0 & 0.0 & 0.0 & 0.0 & 1652.5 & 152.8 & 0.0 \\
\hline$s$ & 0.0 & 0.0 & 0.0 & 0.0 & 0.0 & 0.0 & 0.0 & 0.0 & 60.8 & 0.0 \\
\hline A.1203 & 0.0 & 0.0 & 0.0 & 0.0 & 0.0 & 0.0 & 0.0 & 0.0 & 68.8 & 0.0 \\
\hline $\mathrm{C} 3 \mathrm{H} 602$ & 0.0 & 0.0 & 0.0 & 0.0 & 0.0 & 0.0 & 0.0 & 0.0 & 0.0 & 0.0 \\
\hline $\mathrm{C} 4 \mathrm{H} 802$ & 0.0 & 0.0 & 0.0 & 0.0 & 0.0 & 0.0 & 0.0 & 0.0 & 0.0 & 0.0 \\
\hline C:4 & 0.0 & 0.0 & 0.0 & 0.0 & 0.0 & 0.0 & 0.9 & 0.0 & 0.0 & 0.0 \\
\hline$c 2: 16$ & 0.0 & 0.0 & 0.0 & 0.0 & 0.0 & 0.0 & 0.0 & 0.0 & 0.0 & 0.0 \\
\hline $\mathrm{HCl}$ & 0.0 & 0.0 & 0.0 & 0.0 & 0.0 & 0.0 & 0.0 & 0.0 & 0.0 & 0.0 \\
\hline C12 & 0.0 & 0.0 & 0.0 & 0.0 & 0.0 & 0.0 & 0.0 & 0.0 & 0.9 & 0.0 \\
\hline CHN & 0.0 & 0.0 & 0.0 & 0.0 & 0.0 & 0.0 & 0.0 & 0.0 & 0.0 & 0.0 \\
\hline $\mathrm{kmol} / \mathrm{hz}$ & 8052.4 & 8062.4 & 1652.5 & 6146.8 & 6246.8 & 73.4 & 5422.1 & 1652.5 & 5462.4 & 2.9 \\
\hline $\mathrm{kg} / \mathrm{hz}$ & 231341.0 & 231341.0 & 52880.0 & $: 72110.4$ & 172110.4 & 2936.0 & 119849.2 & 52880.0 & 62313.7 & 290.0 \\
\hline Temo. (C) & 262.0 & 25.0 & 25.0 & 25.0 & 25.0 & 25.0 & 1300.0 & 40.0 & 25.0 & 25.0 \\
\hline P-ess (K & 517.2 & 103.4 & 517.1 & 5.2 .2 & $\equiv \vdots 7.1$ & $5: 7.2$ & 8135.8 & 8135.8 & 103.4 & $\$ 03.4$ \\
\hline
\end{tabular}




\begin{tabular}{|c|c|c|c|c|c|c|c|c|c|c|}
\hline & $0: 2$ & 013 & 014 & 015 & 017 & $017 A$ & 0173 & 970 & $0: 8$ & 019 \\
\hline$A=$ & 0.0 & 0.0 & 0.0 & 0.0 & 0.0 & 0.0 & 0.0 & 0.0 & 0.0 & 0.0 \\
\hline$C$ & 0.0 & 3613.7 & 0.0 & 0.0 & 0.0 & 0.0 & 0.0 & 0.0 & 0.0 & 0.0 \\
\hline $\mathrm{CH} 30 \mathrm{H}$ & 0.0 & 0.0 & 0.0 & 0.0 & 0.0 & 0.0 & 0.0 & 0.0 & 0.0 & 0.0 \\
\hline C2:50\% & 0.0 & 0.0 & 0.0 & 0.0 & 0.0 & 0.0 & 0.0 & 0.0 & 0.0 & 0.0 \\
\hline $03470 \div$ & 0.0 & 0.0 & 0.0 & 0.0 & 0.0 & 0.0 & 0.0 & 0.0 & 0.0 & 0.0 \\
\hline $04590: 4$ & 0.0 & 0.0 & 0.0 & 0.0 & 0.0 & 0.0 & 0.0 & 0.0 & 0.0 & 0.0 \\
\hline C5:1:05 & C.C & 0.0 & 0.0 & 0.0 & 0.0 & 0.0 & 0.0 & 0.0 & 0.0 & 0.0 \\
\hline $\mathrm{CO}$ & 0.0 & 0.0 & 0.0 & 0.0 & 986.1 & 0.0 & 986.1 & 986.1 & 3638.4 & 0.0 \\
\hline $\mathrm{CO2}$ & 275.3 & 275.3 & 0.0 & 0.0 & 230.7 & 0.0 & 230.7 & 230.7 & 217.3 & 0.0 \\
\hline $\cos$ & 0.0 & 0.0 & 0.0 & 0.0 & 0.0 & 0.0 & 0.0 & 0.0 & 4.8 & 0.0 \\
\hline $\mathrm{Cac03}$ & 0.0 & 2.9 & 0.0 & 0.0 & 0.0 & 0.0 & 0.0 & 0.0 & 0.0 & 0.0 \\
\hline 32 & 0.0 & 2465.6 & 0.0 & 0.0 & $388: .0$ & 0.0 & 3881.0 & 3881.0 & 1322.4 & 0.0 \\
\hline 320 & 0.0 & 69.3 & 0.0 & 2877.8 & 0.0 & 152.8 & 1430.3 & 2430.3 & 152.8 & 0.0 \\
\hline$\because 25$ & 0.0 & 0.0 & 0.0 & 0.0 & 0.0 & 0.0 & 0.0 & 0.0 & 55.3 & 0.0 \\
\hline$\therefore 2$ & 0.0 & 30.5 & 0.0 & 0.0 & 0.0 & 0.0 & 0.0 & 0.0 & 29.4 & 0.0 \\
\hline Ni:3 & 0.0 & 0.0 & 0.0 & 0.0 & 0.0 & 0.0 & 0.0 & 0.0 & 1.0 & 0.0 \\
\hline 02 & 0.0 & 152.8 & 0.0 & 0.0 & 0.0 & 0.0 & 0.0 & 0.0 & 0.0 & 0.0 \\
\hline$s$ & 0.0 & 60.8 & 0.0 & $0 . \overline{0}$ & 0.0 & 0.0 & 0.0 & 0.0 & 0.0 & 0.0 \\
\hline$A 2203$ & 0.0 & 68.8 & 0.0 & 0.0 & 0.0 & 0.0 & 0.0 & 0.0 & 0.0 & 0.0 \\
\hline C3:602 & 0.0 & 0.0 & 0.0 & 0.0 & 0.0 & 0.0 & 0.0 & 0.0 & 0.0 & 0.0 \\
\hline C45802 & 0.0 & 0.0 & 0.0 & 0.0 & 0.0 & 0.0 & 0.0 & 0.0 & 0.0 & 0.0 \\
\hline C:4 & 0.0 & 0.0 & 3217.7 & 0.0 & 1.0 & 0.0 & 1.0 & 2.0 & 0.9 & 0.0 \\
\hline$c 2: 5$ & 0.0 & 0.0 & 0.0 & 0.0 & 0.0 & 0.0 & 0.0 & 0.0 & 0.0 & 0.0 \\
\hline HC: & 0.0 & 0.0 & 0.0 & 0.0 & 0.0 & 0.0 & 0.0 & 0.0 & 0.0 & 0.0 \\
\hline$C 22$ & 0.0 & 0.9 & 0.0 & 0.0 & 0.0 & 0.0 & 0.0 & 0.0 & 0.0 & 0.0 \\
\hline $\mathrm{CHN}$ & 0.0 & 0.0 & 0.0 & 0.0 & 0.0 & 0.0 & 0.0 & 0.0 & 0.0 & 0.0 \\
\hline$k n o$ /hs & 275.3 & 5740.6 & 1217.7 & 2877.8 & 5098.8 & 152.8 & 6529.1 & 6529.1 & 5422.2 & 0.0 \\
\hline$x g / h z$ & $: 2: 13.2$ & 74716.9 & 19483.2 & $5: 800.4$ & 45538.8 & 2750.4 & 71284.2 & 71284.2 & $1: 9849.2$ & 0.0 \\
\hline $\operatorname{Temo} \cdot(c)$ & 25.0 & 30.0 & 25.0 & 300.0 & 369.7 & 83.4 & 926.9 & 25.0 & 25.0 & 25.0 \\
\hline Pzess. (KPA) & $: 03.4$ & 8135.8 & 200.0 & 200.0 & $8: 06.0$ & 8106.0 & 202.0 & 202.0 & $3: 35.8$ & $5: 7.2$ \\
\hline
\end{tabular}


Table 2.5 (cont.)

\begin{tabular}{|c|c|c|c|c|c|c|c|c|c|c|}
\hline- & 020 & 022 & $022 \mathrm{~A}$ & 023 & 024 & 025 & 026 & $026 \mathrm{~A}$ & 027 & 025 \\
\hline$A=$ & 0.0 & 0.0 & 0.0 & 0.0 & 0.0 & 0.0 & 0.0 & 0.0 & 0.0 & 0.0 \\
\hline C & 0.0 & 0.0 & 0.0 & 0.0 & 0.0 & 0.0 & 0.0 & 0.0 & 0.0 & 0.0 \\
\hline $\mathrm{CH} 30 \mathrm{H}$ & $\therefore 8.0$ & 0.0 & 0.0 & 0.0 & 0.0 & 18.0 & 0.0 & 611.6 & 0.0 & 0.0 \\
\hline $\mathrm{C} 2 \mathrm{HSOH}$ & 0.0 & 0.0 & 0.0 & 0.0 & 0.0 & 0.0 & 0.0 & 638.0 & 0.0 & 0.0 \\
\hline $03470 \mathrm{H}$ & 0.0 & 0.0 & 0.0 & 0.0 & 0.0 & 0.0 & 0.0 & 341.0 & 0.0 & 0.0 \\
\hline C4H9O: & 0.0 & 0.0 & 0.0 & 0.0 & 0.0 & 0.0 & 0.0 & 35.6 & 0.0 & 0.0 \\
\hline $054110 \%$ & 0.0 & 0.0 & 0.0 & 0.0 & 0.0 & 0.0 & 0.0 & 0.0 & 0.0 & $0 . c$ \\
\hline $\mathrm{CO}$ & 0.0 & 4624.4 & 4578.2 & 0.0 & 0.0 & 0.0 & 4578.2 & $68: 6.2$ & 0.0 & 0.0 \\
\hline $\mathrm{CO2}$ & 0.0 & 0.0 & 0.0 & 268.8 & 256.8 & 22.4 & 0.0 & 1454.0 & 0.0 & 0.0 \\
\hline $\cos$ & 0.0 & 0.0 & 0.0 & 0.0 & 0.0 & 4.8 & 0.0 & 0.0 & 0.0 & 0.0 \\
\hline $\mathrm{CaCO} 3$ & 0.0 & 0.0 & 0.0 & 0.0 & 0.0 & 0.0 & 0.0 & 0.0 & 0.0 & 0.0 \\
\hline$\because 2$ & 0.0 & 5203.4 & 5151.4 & 0.0 & 0.0 & 0.0 & 5151.4 & 7694.4 & 0.0 & 0.0 \\
\hline$\because 20$ & 0.0 & 0.0 & 0.0 & 0.0 & 0.0 & 0.0 & 0.0 & 136.3 & 0.0 & 189.7 \\
\hline 325 & 0.0 & 0.0 & 0.0 & 0.0 & 0.0 & 55.3 & 0.0 & 0.0 & 0.0 & 0.0 \\
\hline$\therefore 2$ & 0.0 & 0.0 & 0.0 & 0.0 & 29.4 & 0.0 & 0.0 & 0.0 & 0.0 & 0.0 \\
\hline $\mathrm{NH3}$ & 0.0 & 0.0 & 0.0 & 0.0 & 0.0 & 1.0 & 0.0 & 0.0 & 0.0 & 0.0 \\
\hline 02 & 0.0 & 0.0 & 0.0 & 0.0 & 0.0 & 0.0 & 0.0 & 0.0 & 0.0 & 0.0 \\
\hline 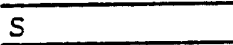 & 0.0 & 0.0 & 0.0 & 0.0 & 0.0 & 0.0 & 0.0 & 0.0 & 0.0 & 0.0 \\
\hline A1203 & 0.0 & 0.0 & 0.0 & 0.0 & 0.0 & 0.0 & 0.0 & 0.0 & 0.0 & 0.0 \\
\hline $\mathrm{C} 3 \mathrm{H} 602$ & 0.0 & 0.0 & 0.0 & 0.0 & 0.0 & 0.0 & 0.0 & 17.6 & 0.0 & 0.0 \\
\hline C4H:802 & 0.0 & 0.0 & 0.0 & 0.0 & 0.0 & 0.0 & 0.0 & 11.6 & 0.0 & 0.0 \\
\hline $\mathrm{CH} 4$ & 0.0 & 2.8 & 1.8 & 0.0 & 0.0 & 0.0 & 1.8 & 431.2 & 431.2 & 0.0 \\
\hline$c 246$ & 0.0 & 0.0 & 0.0 & 0.0 & 0.0 & 0.0 & 0.0 & 17.0 & 17.0 & 0.0 \\
\hline ECl & 0.0 & 0.0 & 0.0 & 0.0 & 0.0 & 0.0 & 0.0 & 0.0 & 0.0 & 0.0 \\
\hline$c 12$ & 0.0 & 0.0 & 0.0 & 0.0 & 0.0 & 0.0 & 0.0 & 0.0 & 0.0 & 0.0 \\
\hline $\mathrm{CHN}$ & 0.0 & 0.0 & 0.0 & 0.0 & 0.0 & 0.0 & 0.0 & 0.0 & 0.0 & 0.0 \\
\hline$k m 01 / h=$ & $: 8.0$ & 9829.6 & 9731.4 & 268.8 & $: 85.2$ & 101.4 & 9731.4 & 38004.4 & 448.2 & $: 89.7$ \\
\hline $\mathrm{kg} / \mathrm{hs}$ & 576.0 & 139918.5 & 138520.6 & 12827.2 & 7722.4 & 3743.0 & 138520.6 & 342414.5 & 7409.2 & $34 \div 4.5$ \\
\hline $\operatorname{Semp} \cdot(C)$ & 25.0 & 83.3 & 83.3 & 83.3 & 83.3 & 83.3 & 169.0 & $3: 0.0$ & $3: 0.0$ & 25.0 \\
\hline Pzess. (KPA) & 203.4 & 8106.0 & 8106.0 & $8: 06.0$ & $8: 06.0$ & 8106.0 & 14190.0 & .2566 .0 & 22656.0 & $5: 2.2$ \\
\hline
\end{tabular}




\begin{tabular}{|c|c|c|c|c|c|c|c|c|c|c|}
\hline & 033 & 034 & 036 & 037 & 038 & 039 & 041 & 042 & 245 & 245 \\
\hline$A=$ & 0.0 & 0.0 & 0.0 & 0.0 & 0.0 & 0.0 & 0.0 & 0.0 & 0.0 & 0.0 \\
\hline$C$ & 26.6 & 0.0 & 0.0 & 26.6 & 0.0 & 0.0 & 0.0 & 0.0 & 0.0 & 3.0 \\
\hline $\mathrm{CH} 3 \mathrm{OH}$ & 0.0 & 0.0 & 0.0 & 0.0 & 0.0 & 0.0 & 18.0 & 0.0 & $: 8.0$ & 0.0 \\
\hline C2H50: & 0.0 & 0.0 & 0.0 & 0.0 & 0.0 & 0.0 & 0.0 & 0.0 & 0.0 & 0.0 \\
\hline $\mathrm{C} 3 \mathrm{H} 7 \mathrm{OH}$ & 0.0 & 0.0 & 0.0 & 0.0 & 0.0 & 0.0 & 0.0 & 0.0 & 0.0 & 5.0 \\
\hline C4H9OH & 0.0 & 0.0 & 0.0 & 0.0 & 0.0 & 0.0 & 0.0 & 0.0 & 0.0 & 2.0 \\
\hline C5H110H & 0.0 & 0.0 & 0.0 & 0.0 & 0.0 & 0.0 & 0.0 & 0.0 & 0.0 & 0.0 \\
\hline $\mathrm{CO}$ & 0.0 & 0.0 & 0.0 & 0.0 & 46.2 & 0.0 & 0.0 & 0.0 & 0.0 & 0.0 \\
\hline $\mathrm{CO} 2$ & 0.0 & 0.0 & 0.0 & 0.0 & 0.0 & 0.0 & 22.4 & 0.0 & 22.4 & 2.0 \\
\hline $\cos$ & 0.0 & 0.0 & 0.0 & 0.0 & 0.0 & 0.0 & 0.0 & 0.0 & 4.8 & 0.0 \\
\hline $\mathrm{CaCO} 3$ & 2.9 & 0.0 & 0.0 & 2.9 & 0.0 & 0.0 & 0.0 & 0.0 & 0.0 & 0.0 \\
\hline 32 & 0.0 & 0.0 & 0.0 & 0.0 & 52.0 & 0.0 & 0.0 & 0.0 & 0.0 & 0.0 \\
\hline 520 & 0.0 & 251.2 & 251.2 & 0.0 & 0.0 & 0.0 & 0.0 & 0.0 & 49.8 & 0.0 \\
\hline $32 S$ & 0.0 & 0.0 & 0.0 & 0.0 & 0.0 & 0.0 & 55.3 & 0.0 & 5.5 & 0.0 \\
\hline N2 & 0.0 & 0.0 & 0.0 & 0.0 & 0.0 & 89.0 & 0.0 & 90.2 & 90.2 & 0.0 \\
\hline N.3 & 0.0 & 0.0 & 0.0 & 0.0 & 0.0 & 0.0 & 1.0 & 0.0 & .0 & 0.0 \\
\hline 02 & 0.0 & 0.0 & 0.0 & 0.0 & 0.0 & 32.0 & 0.0 & 31.9 & 7.0 & 0.0 \\
\hline$s$ & 0.8 & 0.0 & 0.0 & 0.8 & 0.0 & 0.0 & 0.0 & 0.0 & 0.0 & 49.8 \\
\hline A1203 & 58.8 & 0.0 & 0.0 & 68.8 & 0.0 & 0.0 & 0.0 & 0.0 & 0.0 & 0.0 \\
\hline $\mathrm{C} 3 \mathrm{H} 602$ & 0.0 & 0.0 & 0.0 & 0.0 & 0.0 & 0.0 & 0.0 & 0.0 & 0.0 & 0.0 \\
\hline $\mathrm{C} 4 \mathrm{H} 802$ & 0.0 & 0.0 & 0.0 & 0.0 & 0.0 & 0.0 & 0.0 & 0.0 & 0.0 & 0.0 \\
\hline $\mathrm{CH4}$ & 0.0 & 0.0 & 0.0 & 0.0 & 0.0 & 0.0 & 0.0 & 0.0 & 0.0 & 0.0 \\
\hline $\mathrm{C} 246$ & 0.0 & 0.0 & 0.0 & 0.0 & 0.0 & 0.0 & 0.0 & 0.0 & 0.0 & 0.0 \\
\hline $\mathrm{HCl}$ & 1.4 & 0.0 & 0.0 & 1.4 & 0.0 & 0.0 & 0.0 & 0.0 & 0.0 & 0.0 \\
\hline$c: 2$ & 0.2 & 0.0 & 0.0 & 0.2 & 0.0 & 0.0 & 0.0 & 0.0 & 0.0 & 0.0 \\
\hline $\mathrm{CHN}$ & 1.2 & 0.0 & 0.0 & 1.2 & 0.0 & 0.0 & 0.0 & 0.0 & 0.0 & 0.0 \\
\hline $\mathrm{kmol} / \mathrm{hz}$ & 101.8 & 251.2 & 251.2 & 101.8 & 98.2 & 121.0 & 96.7 & 122.1 & $\therefore 98.7$ & is. $\varepsilon$ \\
\hline $\mathrm{kg} / \mathrm{hr}$ & 7747.9 & 4521.6 & 4521.6 & 7747.9 & 1397.9 & 3516.0 & 3458.3 & 3546.4 & 5699.8 & 3533.5 \\
\hline Eemo. (C) & 300.0 & 25.0 & 121.0 & 121.0 & 83.3 & 25.0 & 25.0 & 25.0 & 370.0 & 370.0 \\
\hline Press. (KPA) & $8: 35.8$ & 3447.4 & 103.0 & 103.4 & 8106.0 & 15.0 & 15.0 & $: 03.4$ & $\$ 03.4$ & 203.4 \\
\hline
\end{tabular}




\begin{tabular}{|c|c|c|c|c|c|c|c|c|c|c|}
\hline & 047 & 048 & 050 & 051 & 054 & 056 & $055 \AA$ & 0553 & 257 & こミ \\
\hline$i=$ & 0.0 & & 0.0 & 0.0 & 0.0 & 0.0 & 0.0 & 0.0 & 0.0 & 2.0 \\
\hline $\mathrm{C}$ & 0.0 & & 0.0 & 0.0 & 0.0 & 0.0 & 0.0 & 0.0 & 0.0 & 0.0 \\
\hline C:30: & 0.0 & & 18.0 & 0.0 & 0.0 & 0.0 & 0.0 & 0.0 & 0.0 & 0.0 \\
\hline C2:50: & 0.0 & & 0.0 & 0.0 & 0.0 & 0.0 & 0.0 & 0.0 & 0.2 & 0.0 \\
\hline C3:70: & 0.0 & & 0.0 & 0.0 & 0.0 & 0.0 & 0.0 & 0.0 & 0.0 & 0.0 \\
\hline C4:190\% & 0.0 & & 0.0 & 0.0 & 0.0 & 0.0 & 0.0 & 0.0 & 0.0 & 0.0 \\
\hline C5:120: & 0.0 & & 0.0 & 0.0 & 0.0 & 0.0 & 0.0 & 0.0 & 0.0 & 0.0 \\
\hline $\mathrm{CO}$ & 0.0 & & 0.0 & 0.0 & 0.0 & 6816.1 & 5816.1 & $58: 6.1$ & 0.0 & $5 \Xi 25.2$ \\
\hline $\mathrm{CO2}$ & 0.0 & & 22.4 & 0.0 & 0.0 & 1454.1 & 0.0 & 0.0 & $: 454.2$ & 3454.1 \\
\hline $\cos$ & 0.0 & & 4.8 & 0.0 & 0.0 & 0.0 & 0.0 & 0.0 & 0.0 & 0.0 \\
\hline $\mathrm{CaCO} 3$ & 3.2 & & 0.0 & 0.0 & 0.0 & 0.0 & 0.0 & 0.0 & 0.0 & 0.0 \\
\hline$\because 2$ & 0.0 & & 0.0 & 0.0 & 0.0 & 7693.7 & 7693.7 & 7693.7 & 0.0 & 7593.7 \\
\hline$\because 20$ & 0.0 & & 0.0 & 0.0 & 55.3 & 0.0 & 0.0 & 0.0 & 0.0 & 0.0 \\
\hline$\because 2 \mathrm{~S}$ & 2.0 & & 0.0 & 0.0 & 0.0 & 0.0 & 0.0 & 0.0 & 0.0 & 0.0 \\
\hline$\because 2$ & $: 2.8$ & & 103.0 & 0.0 & 0.0 & 0.0 & 0.0 & 0.0 & 0.0 & 0.0 \\
\hline 83 & 0.0 & & 3.0 & 0.0 & 0.0 & 0.0 & 0.0 & 0.0 & 0.0 & 0.0 \\
\hline 02 & 3.4 & & 7.6 & 0.0 & 0.0 & 0.0 & 0.0 & 0.0 & 0.0 & 0.0 \\
\hline$s$ & 0.0 & & 0.0 & 5.5 & 0.0 & 0.0 & 0.0 & 0.0 & 0.0 & 0.0 \\
\hline A2203 & 0.0 & & 0.0 & 0.0 & 0.0 & 0.0 & 0.0 & 0.0 & 0.0 & 0.0 \\
\hline 039602 & 0.0 & & 0.0 & 0.0 & 0.0 & 0.0 & 0.0 & 0.0 & 0.0 & 0.0 \\
\hline 044802 & 0.0 & & 0.0 & 0.0 & 0.0 & 0.0 & 0.0 & 0.0 & 0.0 & 0.0 \\
\hline $\mathrm{CH} 4$ & 0.0 & & 0.0 & 0.0 & 0.0 & 0.0 & 0.0 & 0.0 & 0.0 & 431.2 \\
\hline $52 \div 5$ & 0.0 & & 0.0 & 0.0 & 0.0 & 0.0 & 0.0 & 0.0 & 0.0 & $\div 7.0$ \\
\hline$\because C:$ & 0.0 & & 0.0 & 0.0 & 0.0 & 0.0 & 0.0 & 0.0 & 0.0 & 0.0 \\
\hline$C: 2$ & 0.0 & & 0.0 & 0.0 & 0.0 & 0.0 & 0.0 & 0.0 & 0.0 & 0.0 \\
\hline $\mathrm{CHOH}$ & 0.0 & & 0.0 & 0.0 & 0.0 & 0.0 & 0.0 & 0.0 & 0.0 & 0.0 \\
\hline$k m 0: 1 x=$ & $: 5.2$ & 0.0 & 156.8 & 5.5 & 55.3 & 15963.9 & 14509.8 & 14509.8 & 2454.1 & 25422.1 \\
\hline$k g / h z$ & 467.2 & \#VALUE! & 4993.0 & 177.0 & 995.4 & 270218.6 & 206238.2 & 206238.2 & 63980.4 & 277627.8 \\
\hline meno.:C: & 25.0 & 25.0 & 370.0 & 370.0 & 370.0 & 310.0 & 25.0 & 38.8 & 320.0 & $3: 0.0$ \\
\hline ?zess. KPS & $: 03.4$ & $: 5.0$ & 103.4 & $: 03.4$ & $: 03.4$ & 12666.0 & 12666.0 & $24: 85.0$ & 12666.0 & 22566.0 \\
\hline
\end{tabular}




\begin{tabular}{|c|c|c|c|c|c|c|c|c|c|c|}
\hline & 053 & 064 & 065 & 067 & 068 & 070 & 071 & 073 & 074 & 075 \\
\hline$A=$ & 0.0 & 0.0 & 0.0 & 62.0 & 0.0 & 0.0 & 0.0 & 0.0 & 0.2 & 62.0 \\
\hline $\mathrm{C}$ & 0.0 & 0.0 & 0.0 & 0.0 & 0.0 & 0.0 & 0.0 & 0.0 & 0.0 & 0.0 \\
\hline CH3OH & 0.0 & 611.6 & 0.0 & 0.0 & 0.0 & 0.0 & 0.0 & 0.0 & 0.0 & 0.0 \\
\hline $\mathrm{C2H5OH}$ & 0.0 & 538.0 & 0.0 & 0.0 & 0.0 & 0.0 & 0.0 & 0.0 & 0.0 & 0.0 \\
\hline C3FiOH & 0.0 & $\$ 41.0$ & 0.0 & 0.0 & 0.0 & 0.0 & 0.0 & 0.0 & 0.0 & 02 \\
\hline C4\%90: & 0.0 & 35.6 & $0 . c$ & 0.0 & 0.0 & 0.0 & 0.0 & 0.0 & 2.0 & 0.0 \\
\hline C5:::0\% & 0.0 & 0.0 & 0.0 & 0.0 & 0.0 & 0.0 & 0.0 & 0.0 & 0.0 & 0.0 \\
\hline SO & 0.0 & 0.0 & 0.0 & 0.0 & 0.0 & 0.0 & 0.0 & 2.0 & 2.2 & 0.0 \\
\hline $\mathrm{CO2}$ & 0.0 & 0.0 & 0.0 & 0.0 & 0.0 & 0.0 & 0.0 & 0.0 & 2.2 & 455.3 \\
\hline $\cos$ & 0.0 & 0.0 & 0.0 & 0.0 & 0.0 & 0.0 & 0.0 & 0.0 & 0.5 & 0.0 \\
\hline $\mathrm{CaCO}^{3}$ & 0.0 & 0.0 & 0.0 & 0.0 & 0.0 & 0.0 & 0.0 & 0.0 & 0.2 & 2.2 \\
\hline 52 & 0.2 & 0.0 & 0.0 & 0.0 & 0.0 & 0.0 & 0.0 & 0.0 & 0.0 & 2.0 \\
\hline 120 & 335.3 & 0.0 & 422.5 & 0.0 & 3840.0 & 0.0 & 3840.0 & $3: 00.0$ & $3: 00.2$ & $8 \equiv 3.7$ \\
\hline 525 & 0.0 & 0.0 & 0.0 & 0.0 & 0.0 & 0.0 & 0.0 & 0.0 & $2 .=$ & 0.0 \\
\hline$\therefore 2$ & 0.0 & 0.0 & 0.0 & 4827.6 & 0.0 & 0.0 & 0.0 & 0.0 & 0.2 & 4327.5 \\
\hline $\mathrm{NH3}$ & 0.0 & 0.0 & 0.0 & 0.0 & 0.0 & 0.0 & 0.0 & 0.0 & 0.2 & 0.0 \\
\hline 02 & 0.0 & 0.0 & 0.0 & 1292.0 & 0.0 & 0.0 & 0.0 & 0.0 & 0.8 & 370.0 \\
\hline$S$ & 0.0 & 0.0 & 0.0 & 0.0 & 0.0 & 0.0 & 0.0 & 0.0 & 0.0 & 0.0 \\
\hline$A 1203$ & 0.0 & 0.0 & 0.0 & 0.0 & 0.0 & 0.0 & 0.0 & 0.0 & 0.0 & 0.0 \\
\hline $\mathrm{C} 3 \mathrm{H} 602$ & 27.6 & 0.0 & 0.0 & 0.0 & 0.0 & 0.0 & 0.0 & 0.0 & 2.2 & 0.0 \\
\hline $\mathrm{C} 4 \mathrm{H8O2}$ & 11.6 & 0.0 & 0.0 & 0.0 & 0.0 & 0.0 & 0.0 & 0.0 & 0.0 & 0.0 \\
\hline $\mathrm{CH} 4$ & 0.0 & 0.0 & 0.0 & 0.0 & 0.0 & 431.0 & 0.0 & 0.0 & 0.0 & 0.0 \\
\hline $\mathrm{C} 2 \mathrm{H6}$ & 0.0 & 0.0 & 0.0 & 0.0 & 0.0 & 17.0 & 0.0 & 0.0 & 0.0 & 0.0 \\
\hline $4 \mathrm{Cl}$ & 0.0 & 0.0 & 0.0 & 0.0 & 0.0 & 0.0 & 0.0 & 0.0 & 0.0 & 0.0 \\
\hline$C 12$ & 0.0 & 0.0 & 0.0 & 0.0 & 0.0 & 0.0 & 0.0 & 0.0 & 0.2 & 0.0 \\
\hline CFN & 0.0 & 0.0 & 0.0 & 0.0 & 0.0 & 0.0 & 0.0 & 0.0 & 0.5 & 0.0 \\
\hline $\mathrm{kmol} / \mathrm{hr}$ & $: 65.5$ & 1426.2 & 422.5 & 6181.6 & 3840.0 & 448.0 & 3840.0 & 3100.0 & $3: 00.2$ & $5 \equiv-8.5$ \\
\hline $\mathrm{kg} / \mathrm{hz}$ & 4776.5 & 60013.1 & 7605.0 & 178996.8 & 69120.0 & 7406.0 & 59120.0 & 55800.0 & $5 \equiv 800.0$ & $\vdots E \equiv \Xi \vdots 2.2$ \\
\hline gemo. (C) & $3: 0.0$ & 310.0 & 25.0 & 25.0 & 482.0 & 227.0 & 20.0 & 20.0 & 482.2 & $\because \therefore 25.0$ \\
\hline P=ess. (KPB) & $: 2566.0$ & 22666.0 & 103.4 & $: 03.4$ & 10450.0 & 201.3 & 10000.0 & 20000.0 & 30400.2 & $: 02.3$ \\
\hline
\end{tabular}




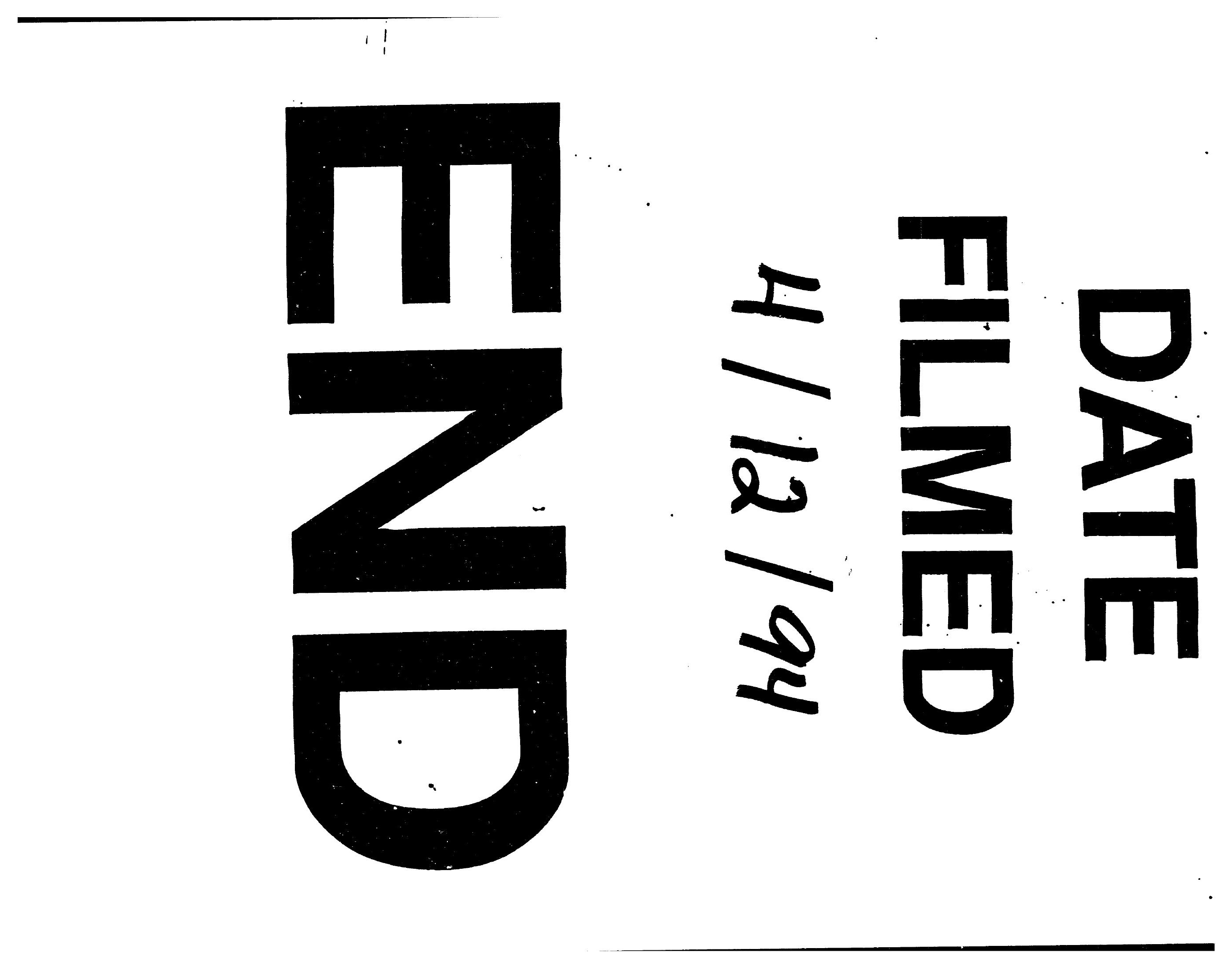

